\title{
Metropolis, Money and Markets
}

This book explores the impact of finance on urban spaces as well as cities' role in the social constitution and dissemination of financial logics and techniques. It brings together literature from different disciplinary areas to increase our understanding of financialization.

It observes how non-financial members of society, such as public bureaucrats, urban planners, the media and so on, are actively involved in the financialization of urban areas. With an explicit focus on Brazil, a developing country in the Global South, the book demonstrates how the country has been grappling with complex and contradictory processes of neoliberalization, decentralization, re-democratization and institutional-legal strengthening of frameworks for urban and regional planning, stressing the relations between urban space and finance capital.

With a distinct view of filling a gap in the current literature on urban financialization, the book aims to focus on less developed areas in this field and link them with the literature on social studies of finance. This makes the text relevant for academics and scholars of urban studies and planning theory, geography, development studies and political economy, as well as scholars in the US and Europe interested in understanding Brazilian patterns of financialization.

Jeroen Klink is a Dutch economist who works as a professor of economics and urban planning at the Universidade Federal do ABC (São Paulo, Brazil). He has published several books and papers on metropolitan governance, economic restructuring in cities and the role of finance. 


\section{Global Urban Studies}

Series Editor: Laura Reese

Michigan State University, USA

This series is published in conjunction with the School of Planning, Design, and Construction at Michigan State University, USA.

Providing cutting edge interdisciplinary research on spatial, political, cultural and economic processes and issues in urban areas across the US and the world, books in this series examine the global processes that impact and unite urban areas. The organizing theme of the book series is the reality that behavior within and between cities and urban regions must be understood in a larger domestic and international context. An explicitly comparative approach to understanding urban issues and problems allows scholars and students to consider and analyse new ways in which urban areas across different societies and within the same society interact with each other and address a common set of challenges or issues. Books in the series cover topics which are common to urban areas globally, yet illustrate the similarities and differences in conditions, approaches, and solutions across the world, such as environment/brownfields, sustainability, health, economic development, culture, governance and national security. In short, the Global Urban Studies book series takes an interdisciplinary approach to emergent urban issues using a global or comparative perspective.

\section{Twin Cities}

Urban Communities, Borders and Relationships over Time

Edited by John Garrard and Ekaterina Mikhailova

\section{Disassembled Cities}

Social and Spatial Strategies to Reassemble Communities

Edited by Elizabeth L. Sweet

\section{Metropolis, Money and Markets}

Brazilian Urban Financialization in Times of Re-emerging Global Finance Jeroen Klink

For more information about this series, please visit: www.routledge.com/ Global-Urban-Studies/book-series/ASHSER-1385 


\title{
Metropolis, Money and Markets
}

Brazilian Urban Financialization in Times of Re-emerging Global Finance

\author{
Jeroen Klink
}

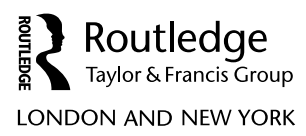


First published 2020

by Routledge

2 Park Square, Milton Park, Abingdon, Oxon OX14 4RN

and by Routledge

52 Vanderbilt Avenue, New York, NY 10017

Routledge is an imprint of the Taylor \& Francis Group, an informa business

(C) 2020 Jeroen Klink

The rights of Jeroen Klink to be identified as the author of this work has been asserted by him in accordance with sections 77 and 78 of the Copyright, Designs and Patents Act 1988.

All rights reserved. No part of this book may be reprinted or reproduced or utilised in any form or by any electronic, mechanical, or other means, now known or hereafter invented, including photocopying and recording, or in any information storage or retrieval system, without permission in writing from the publishers.

Trademark notice: Product or corporate names may be trademarks or registered trademarks, and are used only for identification and explanation without intent to infringe.

British Library Cataloguing-in-Publication Data

A catalogue record for this book is available from the British Library

Library of Congress Cataloging-in-Publication Data

A catalog record for this book has been requested

ISBN: 978-0-367-18078-2 (hbk)

ISBN: 978-0-429-05943-8 (ebk)

Typeset in Times New Roman

by Apex CoVantage, LLC 


\section{Contents}

Acknowledgements vi

Introduction 1

1 A conceptual primer on (urban) financialization 16

2 State spaces, financialization of cities and the urbanization of finance in the Global South

3 State spaces, urban rents and finance in the Brazilian development trajectory

4 Planning, projects and profitability: The role of financial and institutional devices in the urbanization of finance

5 On contested water governance and the making of urban financialization: Exploring the case of metropolitan São Paulo, Brazil

6 Building within the limits? A closer look at the "My House, My Life" Program in the outskirts of metropolitan São Paulo

7 On reframing the capital market-austerity nexus and the emerging governance of urban securitization

Conclusion 


\section{Acknowledgements}

Sections 4.2 and 4.3 are reprinted from the Land Use Policy, Volume, 69, journal, Jeroen Klink and Lais Eleonora Maróstica Stroher, "The Making of Urban Financialization? An exploration of Brazilian urban partnership operations with building certificates", pages 521-526 (2017), published by Elsevier. Sections 5.2, 5.3 and 5.4 first appeared online in the journal, Urban Studies, Jeroen Klink, Vanessa Lucena Empinotti and Marcelo Aversa, "On contested water governance and the making of urban financialization: Exploring the case of metropolitan São Paulo, Brazil, pages 6-20 (2019), published by Sage. I would like to thank the editors and publishers of these journals for permission to republish part of these articles here. Figure 5.1 (Evolution of nominal share price of SABESP (2002-2018)) is taken with permission from Lucas Daniel Ferreira. Finally, the research on which part of this book is based received support from the agency Conselho Nacional de Desenvolvimento Científico e Tecnológico (CNPQ) (i.e. National Council for Scientific and Technological Development), through Grant No. 307069/2017-6 from the Brazilian Ministry for Science, Technology, Innovation and Communication. 


\section{Introduction}

Particularly since the 2007/08 US subprime mortgage meltdown, which triggered what can probably be considered as one of the worst crises in the world economy since the 1929 crash, academic research on financialization has proliferated rapidly. Aalbers (2015: 214) has defined the concept as "the increasing dominance of financial actors, markets, practices, measurements and narratives, at various scales, resulting in a structural transformation of economies, firms (including financial institutions), states and households".

Although the variety in methodological approaches and disciplinary perspectives makes it difficult to generalize, it is nevertheless possible to detect specific strands in the literature on financialization (Zwan, 2014), such as Marxian, regulationist or Post-Keynesian political economy (e.g. see Hilferding, 1910; Chesnais, 1997; and Minsky, 1996, respectively); critical management studies and shareholder governance (Froud et al., 2006); social studies of finance, including work on the performativity of economic-financial models (Mackenzie, 2006; Berndt and Boeckler, 2009); and financial geography (French et al., 2011).

Political economy has emphasized structural transformations in the generation of a finance-driven mode of accumulation and regulation that "exploits all of us without producing" (Lapavitsas, 2013).

Work on critical management studies and shareholder governance has used corporate finance and principal-agent theory (Fama, 1980) in order to flesh out the contradictory reshaping of organizations and governance under the influence of shareholder value, structured around the premise of maximizing capital gains and dividends (Froud et al., 2002; Erturk et al., 2007).

Social studies of finance have prioritized the investigation of the mechanisms through which finance has penetrated into the reproduction of daily life, for example, through credit cards, small-scale saving schemes and micro-finance, consumer credit, mortgages and private health and retirement plans. This literature describes how the hollowing out of welfare regimes has shifted responsibilities and insurances from the state to the investing subject. The focus becomes on how, particularly in relation to non-elite actors, "risk itself becomes the motivating force to enter financial markets for protection against possible unemployment, poor health or retirement" (Zwan, 2014: 112). For Martin (2002), life itself has become an 


\section{Introduction}

asset that requires to be managed. Related research has emerged on how individual subjectivities and the circulation of norms, expectations and conventions in social networks have shaped collective calculative practices and the pricing and valuation in housing markets (Munro and Smith, 2008). Along similar lines, work on performativity has argued that economic and financial theories, models and techniques not only describe the reality of the stock exchange but potentially contribute to constitute and format these markets (Callon, 1998; Mackenzie, 2006). Similar investigations have indicated a gradual financialization of valuation and pricing practices as well. Chiapello (2015), for instance, discusses how a key metric used in financial economics for the (e)valuation of projects and programs (i.e. the net present value of expected flows of income associated with a particular asset) has changed traditional "historical-cost" accounting practices for assets into a valuation approach whereby asset prices instead reflect their "projected" future earning capacity (see Chapters 1 and 2).

Finally, financial geography has stressed the variegated and intrinsically uneven spatial character of financialization whereby "money flows like mercury", "pooling” in particular places and spaces (Hall, 2010: 240). Aalbers (2019: 2) argues that, while its traditional concern, "as a sub-sub-discipline embedded in economic geography", has been "the research of financial centres and districts", financial geography has increasingly stretched "its frontier to the intersection of economic and urban geography".

This book aims to provide at least three interrelated contributions to this growing literature on finance increasingly dominating the economy, society and daily life.

First, and working along the lines of some of the sceptics such as Christophers (2015), much research has lost political relevance through its rather "reactive focus" by assuming financialization as a starting point and investigating its consequences in terms of "what finance does" in the daily life of others, mostly non-financial actors, through the extraction of value without producing. However, in this book we broaden the research focus by trying to increase our understanding of "what finance is" and how it is socially and politically constituted. To be specific, such a perspective doesn't deny the existence of broader patterns marked by an increasing penetration of finance into the economy, politics and society but allows for a closer articulation between political economy - with its priority on the generation and extraction of value, while, by and large, taking markets for granted - and more open-ended social studies of finance-inspired work (Christophers, 2014). The latter is focussed on fleshing out "the black box of finance" itself, including the metrics, collective agencies and circulation of norms and conventions in professional communities. This involves analyzing the entanglements between financial and non-financial actors alike in the design of pricing and valuation practices that accompany "the making of" markets and financialization itself. Moreover, such an approach has the potential to increase the political relevance of research on financialization by providing fresh entrance points and ammunition for the design of counterhegemonic projects and strategies aimed at what Polanyi (2001) called the re-embedding of deregulated financial markets 
back into society through a "robust palimpsest of social, cultural, political, and regulatory constraints and controls" (Kirkpatrick, 2016: 56; Fields, 2014).

$* * *$

A second contribution of this book is the development of an analytical story line and associated empirical work on financialization as a specifically urbanmetropolitan phenomenon. This implies going beyond financialization in cities towards studying financialization of cities and through cities in times of re-emerging global finance. To be clear, we don't deny the literature has recognized that financialization has effected and is also influenced by cities in the postBretton Woods setting (Theurillat and Vera-Büchel, 2016; O’Neil, 2018). It has engaged with at least four interconnected themes (i.e. financialization of urban land; entrepreneurialism, urban governance and large urban development projects; infrastructure financialization; and the city-capital market nexus).

Although Harvey (1982), based on Marx, already in the 1980s analyzed the tendency of land to be transformed into a financial asset, more recent literature has now started to flesh out the specific geographic and historical circumstances under which this occurs, including an analysis on the limits of the process itself and specific case studies on countries such as Singapore (Haila, 1988) and the Asian developmental states (Haila, 2016; Aveline-Dubach, 2016). Other authors have examined the role of the state in the financialization of public land (e.g. Christophers, 2017 for the UK case) or how land banks have been used within corporate strategies (e.g. see Sanfelici, 2013 on how Brazilian developers used land banks in order to finance the speculative expansion of their market shares).

A second theme (i.e. the articulations between urban neoliberalization and large urban redevelopment projects) is also not new in the literature (Brenner, 2000; Swyngedouw et al., 2002). Nevertheless, recent work has innovated with an analysis on how the entanglements between financial and non-financial actors alike in redevelopment projects tend to transform city space into a "portfolio of tradable income yielding assets" (Guironnet and Halbert, 2015). This has included growing empirical evidence on the role of finance in the design and implementation of projects (Kaika and Rugierro, 2016; Charnock et al., 2014) as well as in the financialization of entrepreneurialism itself through the involvement of the (local) state in mobilizing finance for the delivery of land, infrastructure and real estate (Savini and Aalbers, 2016; Charnock et al., 2014; Klink and Stroher, 2017).

In relation to the third theme, that is, infrastructure finance, the entrance point of the literature has been Graham and Marvin's (2001) path-breaking work on state rescaling, neoliberal infrastructure transitions and splintering urbanism. A common thread in the discussions has been the "relational role" of finance in generating innovative products aimed at the repackaging of illiquid, high-risk and lumpy infrastructure networks into desirable investment assets, and receiving a premium for exactly doing that (Pryke and Allen, 2017; Torrance, 2008). Nevertheless, the unbundling, disassembling and re-assembling of "un-cooperative" urban commons (Bakker, 2007: 447), marked by high initial investment costs, 


\section{Introduction}

significant state involvement, long payback periods and risks, have resulted in disappointing results in terms of additional investments (Bayliss, 2014). A series of case studies in countries such as Spain, Argentina, Chile and the UK, among others, have pointed out the complexities and the "muddy waters of financialization" (March and Purcell, 2014: 17). Interestingly, research on infrastructure finance and financialization has also shown methodological diversity, from political economy approaches to theoretical perspectives influenced by more contingent "mezzanine-level conceptualizations", based on analysis regarding the interactions between entrepreneurial, organizational and regulatory restructuring (O’Neill, 2018). Although there is not much research on infrastructure financialization in the Global South, recent work has been undertaken on infrastructure in general (see Hildyard, 2016) or on specific sectors such as basic sanitation (Bakker, 2007; Britto and Rezende, 2017). Likewise, the number of case studies on infrastructure financialization in specific cities in the Global South is increasing (see, for example Klink et al. (2019) on metropolitan São Paulo, Brazil).

A final theme in the literature on cities in times of financialization is how neoliberalization and austerity have both renewed and made the entanglements between cities and capital markets increasingly complex. This has generated work on heterodox instruments of municipal finance such as tax increment finance districts (Weber, 2010); the management of risks in concessions, private-public partnerships (Ashton et al., 2016) and municipal operations in the capital markets; the disciplinary, postpolitical effects of capital markets on city governance (Peck and Whiteside, 2016); and the increasingly speculative operating of credit markets by municipalities (Kirkpatrick, 2016). Although in Brazil local and state governments are restricted by national regulation to access capital markets, recent research has investigated how municipalities have creatively bypassed this national framework in order to mobilize credit under non-transparent and contradictory conditions (Canettieri, 2017).

In short, there is no denying that the literature has recognized "financialization in cities" as a research object. At the same time, however, the work undertaken until recently reveals a built-in and unresolved tension between political economyinspired approaches and social studies of finance-oriented work on the relation between finance and urban studies. The former provides a scenario of neoliberal urbanism and finance-dominated capitalism structured around the penetration of finance capital in the "city as a receptacle", leaving it little or no local leverage, whereby "the city is overrun by finance" (Theurillat and Vera-Büchel, 2016: 1513). The latter is framed around more contingent and open-ended trajectories, according to which cities have the capacity to invent their own praxis and spaces of financialization whereby "the landing of capital" effectively becomes a "negotiated urban anchoring of finance capital” (Theurillat and Vera-Büchel, 2016).

In this book we argue that investigating what exactly it is that defines finance in cities, as well as how it is socially constituted in city space in the first place by state and non-state actors alike - provides valuable insights into research on what finance capital does in cities (i.e. transforming them into bundles of liquid "tradable income yielding assets") (Guironnet and Halbert, 2015). After all, considering the technological indivisibilities, long payback periods and political 
contestation that accompany the planning and finance of land and infrastructure networks, as well as the organization of pools of metropolitan labour (linked through the tax system to the public budget), there is nothing inherent to the transformation of city space into investment objects (Gotham, 2009). Before finance can penetrate into the reproduction of daily life in cities, it has to be socially constituted through the multi-scalar entanglements between planners, state officials, regulatory agencies, investment bankers and other intermediaries in the making of urban financialization.

There is another value added to stretching the research agenda to the emerging financialization of the "urban condition as such" (and in the end, life itself) instead of focussing on financialization in cities only. The latter approach has somewhat pragmatically adopted a conceptualization of the city "as a container term to include studies of urban governance, housing, real estate and the built environment" (Aalbers, 2019: 2), and triggered work on what is being financialized (more specifically: land, housing, urban infrastructure and environmental resources), how this is being done (neoliberal governance, restructuring the citycapital market nexus, performativity of economic models and devices and so on), but leaving an open question regarding why this process unfolds in the first place. However, as classical critical urban studies on the geography and history of capitalist cities have emphasized earlier on (Soja, 2001; Harvey, 1982; Lefebvre, 2001, Castells, 1977), cities are no containers but represent privileged, albeit contradictory, spaces for the generation, extraction, circulation and (collective) consumption of value in a continuously rescaling and restructuring of states and markets (Clarke and Bradford, 1998; Brenner, 2004). Cities also concentrate on huge social deficits and enormous economic opportunities. Therefore, increasing our understanding of the contemporary urban experience in times of re-emerging global finance requires a perspective that goes beyond financialization in cities.

In this book we develop such an approach. It is based on an investigation of the multiple and variegated entanglements between financialization of cities, on the one hand, and the "urbanization of finance" on the other. We will do so by means of a dialectic moving back and forth between political economy (analyzing what finance does to cities in terms of "extracting value without producing" (Lapavitsas, 2013)) and social studies of finance (investigating how finance is constituted and performed in cities [i.e. the urbanization of finance] in order to provide its "relational" role and innovative financial products). This will also allow us a context-specific and situated understanding of the generation and extraction of rents, value and financial profits, as well as how these processes are connected to the variegated rescaling and restructuring of cities in the contemporary financedriven global economy.

$$
* * *
$$

A third contribution is the book's detailed focus on the geographical and historical trajectory of urban financialization in a country from the Global South. This is not only worthwhile so as to flesh out how this specific experience is different from "finance as we know it" in industrialized countries. Perhaps even more important 


\section{Introduction}

is to see how such a focus contributes to a research agenda whereby thick case studies from the Global South provide a better understanding of the "phenomenon" of financialization itself on the global scale. The latter can be seen in light of the significant fiscal and monetary policy interdependencies and institutionalregulatory entanglements among countries, as well as the international mobility of policies and models, at multiples scales, which have become an inherent part of the shaping of the contemporary world economy and "the production of cities through global-relational connections" (Baker and Temenos, 2015: 825).

To be clear, this implies more than working out the usual claims that the geographical and historical development trajectory of the Global South is different and therefore requires breaking out of existing patterns of trade and finance. This has been the well-known and still-influential approach of the United Nations Economic Commission for Latin America and the Caribbean (ECLAC), structured around the dependency theory notions of centre-periphery and the Global South's continuously deteriorating terms of trade in global commerce. Instead, our starting point is that financialization should be grounded within an understanding according to which cities and countries of the Global South are key players in holding together the "interdependent" (albeit asymmetric) nature of the international financial monetary system. Their massive and costly holdings of international dollar reserves and deflationary management of international capital flows, as well as the contradictory impacts of these policies on domestic socio-institutional and spatial development trajectories, represent only one of the more visible dimensions of this interdependency. Thus, instead of prioritizing the Anglo-Saxon and related contexts, the entrance point here will be the investigation of the multi-scalar "making of" financialization in cities and countries of the Global South as a first step to come to grips with a better understanding of what finance is and how it is reproduced globally (Aglietta, 2018).

Such an analytical lens also allows us to contribute to Peck's (2018) call for building more productive and promising linkages between a political economy/ critical geography perspective (focussed on patterns of "asymmetrical" financialization in the South within an interdependent and unstable global system of monetary governance), on the one hand, and post-structural/post-colonial urban studies, on the other (Robinson, 2011, 2015; Brandão et al., 2018). To be specific, Peck claims that post-structural and postcolonial urban studies have generated valuable contributions to innovative theory by dismantling an essentialist and universalizing narrative, structured around the western city, which has circulated during much of the twentieth century (Healey, 2013). At the same time, however, he identifies the risk of an emerging new divide in urban theory. The latter would arise from a growing distance between efforts that look for broader, structural patterns and generalizability, as opposed to theory-building embedded in the uniqueness and non-comparability of the urban experience, which altogether "appears to make a dialogue between positions and perspectives more, and not less challenging" (Peck, 2018: 171).

We will develop the story line of this book on the basis of the Brazilian setting. Moreover, as far as that is possible and relevant, we establish links with 
international debates and experiences. The choice of Brazil is motivated by two reasons.

First, a book on urban financialization requires "raw material", in our case, cities and what Friedman (2005) called a planning culture embedded within a national framework. ${ }^{1}$ In that sense, Brazil provides an excellent working object considering its development trajectory since the 1930s, driven by state-mediated industrialization and urbanization, which has consolidated a relatively dense national network of cities of different sizes. Moreover, since its re-democratization in the 1980s, the country has gradually built up an internationally acclaimed track record of progressive urban reform and an associated planning culture (Klink and Denaldi, 2015). This was initially triggered, in the midst of macroeconomic crisis and restructuring that characterized the 1980 s, by small-scale slum upgrading strategies driven by progressive mayors, community pressure and "insurgent citizenship" (Holston, 2009) structured around the demand for well-located and affordable land, housing and infrastructure services as basic rights. It was followed, during the 1990s, by a gradual recognition and incorporation of these local approaches into national framework policies. Likewise, the working out of a constitutional chapter on urban reform ultimately culminated in the 2001 approval of a national law called the City Statute. The latter consolidated regulatory-institutional strengthening, which empowered cities, at least theoretically, in collaborative planning efforts framed around redistributive land-use instruments, the reduction of real estate speculation and the provision of affordable, well-located and serviced land for low-income housing. ${ }^{2}$ During 2003-2015, the rise to presidency of successive Worker's Party administrations (Partido dos Trabalhadores, PT) consolidated a social developmental regime of "growth-with-inclusion-without-reforms". It combined a booming economy, abundant liquidity and the implementation of a series of large-scale subsidized flagship programs for slum upgrading (i.e. Programa de Aceleração do Crescimento, PAC, meaning the "National Growth Acceleration Program") and low-income housing (i.e. Minha Casa Minha Vida, MCMV, meaning the program "My House, My Life"), which were financed by the state and built by developers and contractors (Klink and Denaldi, 2014).

Nevertheless, even in the Brazilian literature, the rise and spectacular fall of the Brazilian social-developmental regime during 2003-2015 has not been embedded within a clear analytical reading of its contradictory urban development trajectory and planning culture. ${ }^{3,4}$ To be specific, the demise of social-developmentalism was reflected in the economic and political crisis of the country after 2013, the impeachment of former president Dilma Rouseff in 2015 and imprisonment of former president Luiz Inácio Lula da Silva (Lula) in 2018. Nevertheless, this demise could not be dissociated from the outright disappointing results of Brazilian urban reform itself. The latter had become painfully clear during the proliferation of massive street riots and manifestations in most metropolitan areas in June 2013, triggered by complaints as well as demands for something better (Harvey, 2014). These demands were aggravated by the poor conditions of public transportation and excessively high tariffs, compounded by sprawling land use, real estate speculation and the lack of decent, affordable and well-located housing (Klink 
and Denaldi, 2015; Amore, 2013). Moreover, beneath the surface, the agenda of urban reform itself as well as its "toolkit" of progressive-redistributive land-use instruments had been gradually filled in by developers, contractors and construction firms with active support at multiple scales from the social-developmental state itself (Maricato, 2011; Souza et al., 2019). Thus, telling how this story has unfolded not only provides an "inside zoom" on a particularly contradictory urban trajectory in times of emerging financialization but also sheds light on the somewhat under-researched role of planning and management of cities in explaining the demise of the social-developmental regimes in the Global South itself.

There is a second reason as to why choosing Brazil is particularly adequate for a book with this scope and research method. More specifically, for decades the country has been plagued by a lack of confidence in its own money and currency, as was reflected by chronically high and unstable inflation rates. This has generated enormous challenges to design and consolidate long-term capital markets that would provide credit in order to finance investments, economic growth and the expansion of housing and urban infrastructure. If, as argued by Aglietta (2018: 1), the massive rescue package articulated by the central banks during the Global Financial Crisis (GFC) in mid-September 2008 signalled that "finance and the western economy were saved by money", it also implies that money itself, "as the foundation of value and social belonging" (Aglietta, 2018: 18-80) is crucial to the constitution of financial and capital markets. In that sense, Brazil represents a prime case study in terms of understanding the contradictory rolling back and out of the development state since the mid-1980s and its entanglements with the contradictory insertion of the country into the global monetary order of Post-Bretton Woods. These movements were reflected in initial crisis and austerity measures structured around monetary stabilization, inflation control and the creation of a new currency in 1994 (the "real"), the subsequent state support for the gradual strengthening and deepening of financial and capital markets (Paulani, 2011), as well as the more recent emergence of "financialization of and through the socialdevelopmental state" (Aalbers, 2017) and its contradictory impacts on city spaces.

This book has been written on the basis of a research project that combined a theoretical investigation into urban financialization and its relations with the (re)production of urban space in Brazil, including detailed fieldwork that has been undertaken in metropolitan São Paulo. The latter involved documentary research of files from public and private institutions, collection and systematization of secondary data sets and semi-structured interviews undertaken with planners and government officials, developers, contractors, investment bankers and consultants, among other stakeholders. Part of this work has received financial support from the National Ministry of Science and Technology. ${ }^{5}$

This introduction is followed by seven chapters and a conclusion.

In the first chapter, "A conceptual primer on (urban) financialization", we review the main theoretical approaches to financialization, its linkages with urban studies and planning, as well as the critique that has been raised to the rapidly growing literature. This includes a discussion on the potential for developing a research agenda on urban financialization that takes this critique seriously. 
In the second chapter, "State spaces, financialization of cities and the urbanization of finance in the Global South", we then flesh out the theoretical and empirical contours of such a research program structured around a more articulate linkage between political economy-inspired approaches and social studies of finance in the investigation of the making of financialization, with a central role for cities as privileged spaces for the generation, extraction and circulation of value. The chapter is concluded with an analysis of the relevance of such an approach for shedding light on the Brazilian trajectory.

In Chapter 3, "State spaces, urban rents and finance in the Brazilian development trajectory", we analyze the trajectory of the Brazilian developmental state since the 1960s, with an emphasis on the relations between money, credit and finance and the contradictory (re)production of metropolitan spaces. For readers not familiarized with the Brazilian scenario, it provides a necessary starting point for the case studies on urban financialization in subsequent chapters. In relation to the existing critical literature on Brazilian urban studies, the chapter provides a better articulation between political economy (that tends to ignore or marginalize cities) and the planning literature (rather distant from more detailed discussions on money, credit and finance).

The following four chapters flesh out empirical evidence of the unfolding financialization process, with an emphasis on metropolitan São Paulo. The latter is Brazil's biggest and most dynamic city and the financial capital of the country. It has accumulated more experience than other Brazilian cities in terms of the articulation between its urban planning and management framework and financial markets and therefore represents a logical choice for the purposes of this book.

Chapter 4, "Planning, projects and profitability: The role of financial and institutional devices in the urbanization of finance", which is an extended version of the paper that was published earlier on with Laisa Stroher (Klink and Stroher, 2017), analyzes a specific Brazilian planning instrument as a potential constituent space of urban financialization. More specifically, the sale of securitized building right certificates (CEPACs) in large Urban (Re)development Projects (UDPs) through so-called Urban Partnership Operations, has proliferated rapidly in several cities such as São Paulo, Rio de Janeiro, Belo Horizonte and Curitiba, among others. The chapter explores how planners, financial consultants, contractors and builders/developers effectively shape the contradictory financial and physical design and implementation of UDPs with CEPACs. The initial evidence shows that there are still clear limits to the penetration of finance into city space through CEPACs. Nevertheless, continuing market-enabling regulatory rollout, the capacity of cities such as São Paulo to constantly "innovate" with similar financialinstitutional devices, as well as the increasing activism of foreign investors in buying up depreciated assets of national contractors in light of the recent proliferation of corruption scandals, suggest an open-ended trajectory with a potentially more significant role for financial actors in the design and implementation of Brazilian UDPs.

Chapter 5, "On contested water governance and the making of urban financialization: Exploring the case of metropolitan São Paulo, Brazil”, explores the 
imbricated relations between governance failures and public sector calculative practices in the emerging financialization of infrastructure networks in general and basic sanitation in particular. The specific analysis focuses on how the entanglements between the accumulation of intergovernmental debt, conflicting pricing, capitalization and valuation practices that involve state and municipal water utilities, regulatory and monitoring agencies and consultancies, are key elements in understanding the gradual hollowing out of a system of shared state-municipal water governance and its state-mediated transformation into shareholder governance. The argument is worked out on the basis of a detailed case study on the institutional and financial "battlefield" between listed majority state-owned mixed-capital water company known as, Company for Basic Sanitation of the State of São Paulo (SABESP), and municipal utility, Environmental Sanitation Services of the City of Santo André (SEMASA), a mid-sized city on the fringe of Greater São Paulo.

Chapter 6, "Building within the limits? A closer look at the My House, My Life (MHML) Program in the outskirts of metropolitan São Paulo", presents an analytical reading of the limits and potentials of this federal government's flagship social housing program in times of increasing articulations between (state-driven) finance and real estate, including a detailed case study on its impact in the Greater $\mathrm{ABC}$ region during the period 2009-2014. The latter is a region of seven cities with approximately 3 million inhabitants in the "industrial heartland" of Greater São Paulo (Rodríguez-Pose et al., 2001), which, until the 1970s, concentrated a significant part of the national car industry. Its leadership from labour and social movements and some of its progressive mayors also performed a key role in the gradual emergence of Holston's (2009) "insurgent citizenship" and the transformative praxis in slums and informal settlements since the 1980s. In addition to the detailed discussion on MHML itself, the chapter is concluded with a number of insights regarding the entanglements between city planning and management of land markets, the national design of finance and subsidy guideline in social housing programs and the effective outreach of redistributive urban reform.

Chapter 7, "On reframing the capital market-austerity nexus and the emerging governance of urban securitization", provides an analytical and empirical overview of how the re-emergence of austerity policies has triggered a series of "creative" municipal and state strategies aimed at accessing capital markets in spite of the prevailing Brazilian federal framework that puts restrictions on subnational market operations. After a brief overview of the international literature on crises, austerity and capital markets and its relevance for understanding the Brazilian scenario, a detailed analysis is provided on the emergence and circulation of financial-institutional devices and governance arrangements structured around the creation of "financially independent", state-controlled city and provincial securitization companies. The chapter is concluded with suggestions for further research on the entanglements between crisis narratives and the reframing, restructuring and rescaling of the nexus between urban austerity and capital markets. 
A concluding chapter articulates the Brazilian experience with broader implications for a research agenda on urban financialization with political relevance for the Global South.

\section{Notes}

1 Friedmann (2005: 184) defines planning culture "as the ways, both formal and informal, that spatial planning in a given multi-national region, country or city is conceived, institutionalized, and enacted".

2 For an analysis of the City Statute in terms of its rationale, objectives and main clauses see Carvalho and Rossbach (2010).

3 To be clear, the Brazilian literature has generated several explanations for the rise and fall of the social-developmental regime during the period that the Workers Party (Partido dos Trabalhadores, PT) was in command of the federal administration. Most of them are structured around wrong macroeconomic choices made after 2010 - such as overvalued exchange rates, excessively high interest rates, the particular design of austerity measures which crowded out public investments and so on. (Bresser-Pereira, 2016; Carvalho, 2018) - as well as the weak and unreliable political support received from the elites in finance and industry (Singer, 2015). The blind spot in this literature, however, is the lack of attention to the intrinsically spatial dimensions of the social-developmental regime, which targeted cities and metropolitan regions as privileged arenas, particularly through its multi-billion dollar programs My House My Life (Minha Casa Minha Vida) and the National Growth Acceleration Program (Programa de Aceleração do Crescimento).

4 In a span of a few years, the widely diverging headlines of the financial newspaper, The Economist, managed to express well its perplexity with the Brazilian Development trajectory: "Brazil takes off. Now the risk for Latin America's big success story is hubris". Print Edition, Nov. 12th, 2009, followed by "Has Brazil blown it? A stagnant economy, a bloated state and mass protests mean Dilma Rouseff must change course." Print Edition, September 27th, 2013.

5 More particularly, through National Research Council grant no. 307069/2017-6.

\section{References}

Aalbers MB (2015) The potential for financialization. Dialogues in Human Geography 5(2): 214-219.

Aalbers MB (2017) The variegated financialization of housing. International Journal of Urban and Regional Research 41(4): 542-554.

Aalbers MB (2019) Financial geographies of real estate and the city: A literature review. In: Financial geography working paper series. Leuven: KU Leuven, University of Leuven, January.

Aglietta M (2018) Money: 5000 years of debt and power. Translated by David Broder. London and New York: Verso.

Amore CS (2013) Entre o nó e o fato consumado, o lugar dos pobres na cidade. Um estudo sobre as ZEIS e os Impasses da Reforma Urbana na atualidade. PhD Thesis. University of São Paulo, Faculty of Architecture and Urbanism, São Paulo.

Ashton P; Doussard M and Weber R (2016) Reconstituting the state: City powers and exposures in Chicago's infrastructure leases. Urban Studies 53(7): 1384-1400.

Aveline-Dubach N (2016) Introduction to the special issue: Land and real estate development in the Greater China. Issues \& Studies: A Social Science Quarterly on China, Taiwan and East Asian Affairs 52(4): 1602001 1-11. 


\section{Introduction}

Baker T and Temenos C (2015) Urban policy mobilities research: Introduction to a debate. International Journal of Urban and Regional Research 39(4): 824-827.

Bakker K (2007) The "commons" versus the "commodity": Alter-globalization, antiprivatization and the human right to water in the global South. Antipode 39(3): 430-455.

Bayliss K (2014) The financialization of water. Review of Radical Political Economics 46(3): 292-307.

Berndt C and Boeckler M (2009) Geographies of circulation and exchange: Construction of markets. Progress in Human Geography 33: 535-551.

Brandão CA; Fernández VR and Ribeiro LCQ de (2018) Escalas espaciais, reescalonamentos e estatalidades: lições e desafios para América Latina. Rio de Janeiro: Observatório das Metrópoles e Letra Capital.

Brenner N (2000) The urban question as a scale question: Reflections on Henri Lefebvre's urban theory and the politics of scale. International Journal of Urban and Regional Research 24(2): 361-378.

Brenner N (2004) New state spaces: Urban governance and the rescaling of statehood. Oxford: Oxford University Press.

Bresser-Pereira LZ (2016) Reflexões sobre o Novo Desenvolvimentismo e o Desenvolvimentismo Clássico. Revista de Economia Política 36(2): 237-265.

Britto AL and Rezende SC (2017) A política pública para os serviços urbanos de abastecimento de água e esgotamento sanitário no Brasil: financeirização, mercantilizacão e perspectivas de resistência. Cadernos Metrópole 19(39): 557-581.

Callon M (1998) Introduction: The embeddedness of economic markets in economics. In: Callon M (ed.) The law of markets. Oxford: Blackwell.

Canettieri T (2017) A produção capitalista do espaço e a gestão empresarial da política urbana: o caso da PBH Ativos S/A. Revista brasileira de estudos urbanos e regionais 19(3): 513-529.

Carvalho CS and Rossbach A (orgs.) (2010) The city statute of Brazil: A commentary. São Paulo: Ministry of Cities and Cities Alliance.

Carvalho L (2018) Valsa brasileira. Do boom ao caos econômico. São Paulo: Todavia.

Castells M (1977) The urban question. London: Edward Arnold.

Charnock G; Purcell TF and Ribera-Fumaz R (2014) City of rent the limits to the Barcelona model of urban competitiveness. International Journal of Urban and Regional Research 38(1): 198-217.

Chesnais F (1997) La mondialisation financière. Paris: Syros.

Chiapello E (2015) Financialisation of valuation. Hum Studies 38: 13-35.

Christophers B (2014) From Marx to market and back again: Performing the economy. Antipode 57(1): 12-20.

Christophers B (2015) From financialization to finance: For "de-financialization". Dialogues in Human Geography 5(2): 229-232.

Christophers B (2017) The state and financialisation of public land in the United Kingdom. Antipode 49(1): 62-85.

Clarke DB and Bradford MG (1998) Public and private consumption and the city. Urban Studies 35(5-6): 865-888.

Erturk I; Froud J; Johal S; Leaver A and Williams K (2007) The democratization of finance? Promises, outcomes and conditions. Review of International Political Economy 14(4): 553-575.

Fama EF (1980) Agency problems and the theory of the firm. The Journal of Political Economy 88(2): 288-302. 
Fields D (2014) Contesting the financialization of urban space: Community organizations and the struggle to preserve affordable rental housing in New York City. Journal of Urban Affairs 37(2): 144-165.

French S; Leyshon A and Wainwright T (2011) Financializing space, spacing financialization. Progress in Human Geography 35(6): 798-819.

Friedmann J (2005) Globalization and the emerging culture of planning. Progress in Planning 64: 183-234.

Froud J; Johal S; Leaver A and Williams K (2006) Financialization and strategy: Narratives and numbers. London: Routledge.

Froud J; Johal S and Williams K (2002) Financialization and the coupon pool. Capital and Class 78: 119-152.

Gotham KF (2009) Creating liquidity out of spatial fixity: The secondary circuit of capital and the subprime mortgage crisis. International Journal of Urban and Regional Research 33(2): 355-371.

Graham S and Marvin S (2001) Splintering urbanism: Networked infrastructures, technological mobilities and the urban condition. London and New York: Routledge.

Guironnet A and Halbert L (2015) Urban development projects, financial markets, and investors: A research note. LATTS (Laboratoire, Techniques, Territoires et Sociétés). Chairville: École des Ponts Paritech.

Haila A (1988) Land as a financial asset: The theory of urban rent as a mirror of economic transformation. Antipode 20(2): 79-100.

Haila A(2016) Urban land rent: Singapore as a property state. West Sussex: Wiley Blackwell.

Hall S (2010) Geographies of money and finance I: Cultural economy, politics and place. Progress in Human Geography 35(2): 234-245.

Harvey D (1982) The limits to capital. Oxford: Blackwell.

Harvey D (2014) Cidades Rebeldes. São Paulo: Martins Fontes.

Healey P (2013) Circuits of knowledge and techniques: The transnational flow of planning ideas and practices. International Journal of Urban and Regional Research 37(5): $1510-1526$.

Hildyard N (2016) Licensed larceny. Manchester: Manchester University Press.

Hilferding R (1981 [1910]) Finance capital. London: Routledge \& Kegan Paul.

Holston J (2009) Insurgent citizenship in an era of global urban peripheries. City \& Society 21(2): 234-267.

Kaika M and Rugierro L (2016) Land financialization as a "lived" process: The transformation of Milan's Bicocca by Pirelli. European Urban and Regional Studies 23(1): 3-22.

Kirkpatrick LO (2016) The new urban fiscal crisis: Finance, democracy, and municipal debt. Politics and Society 44(1): 45-80.

Klink J and Denaldi R (2014) On financialization and state spatial fixes in Brazil: A geographical and historical interpretation of the housing program My House My Life. Habitat International 44: 220-226.

Klink J and Denaldi R (2015) On urban reform, rights and planning challenges in the Brazilian metropolis. Planning Theory 15(4): 402-417.

Klink J; Empinotti VL and Aversa M (2019) On contested water governance and the making of urban financialization: Exploring the case of metropolitan São Paulo. Urban Studies, forthcoming.

Klink J and Stroher L (2017) The making of urban financialization? An exploration of Brazilian urban partnership operations with building certificates. Land Use Policy 69: 519-528. 


\section{Introduction}

Lapavitsas C (2013) Profiting without producing: How finance exploits all of us. London and New York: Verso.

Lefebvre H (2001) O Direito à cidade. Translated by Rubens Eduardo Frias. São Paulo: Centauro.

MacKenzie D (2006) An engine, not a camera: How financial models shape markets. Cambridge, MA: The MIT Press.

March H and Purcell T (2014) The muddy waters of financialisation and new accumulation strategies in the global water industry: The case of AGBAR. Geoforum 53: 11-20.

Maricato E (2011) Impasses da política urbana no Brasil. São Paulo: Vozes.

Martin R (2002) Financialization of daily life. Philadelphia: Temple University Press.

Minsky H (1996) Uncertainly and the institutional structure of capitalist economies. Working Paper 155. The Levy Economics Institute of Bard College, Annadale-on-Hudson, New York.

Munro M and Smith SJ (2008) Calculated affection? Charting the complex economy of home purchase. Housing Studies 23(2): 349-367.

O'Neill P (2018) The financialisation of urban infrastructure: A framework of analysis. Urban Studies. Online First. Available at: https://doi.org/10.1177\%2F0042098017751983 (Accessed 21 September 2018).

Paulani LM (2011) A inserção da economia brasileira no cenário mundial: uma reflexão sobre o papel do Estado e sobre a situação atual real à luz da história. In: Logros e Retos del Brasil Contemporâneo. Cidade de México, México, 24 a 26 de Agosto de 2011. UNAM.

Peck J (2018) Novas direções na teoria urbana: para além da comparação? In: Brandão CA; Fernández VR and Ribeiro LCQ de (eds.) Escalas Espaciais, Reescalonamentos e Estatalidades: lições e desafios para América Latina. Rio de Janeiro: Letra Capital \& Observatório das Metrópoles, pp. 167-222.

Peck J and Whiteside H (2016) Financializing Detroit. Economic Geography 92(3): 235-268.

Polanyi K (2001) The great transformation: The political and economic origins of our times. 2nd Edition. Boston: Beacon Press.

Pryke M and Allen J (2017) Financialising urban water infrastructure: Extracting local value, distributing value globally. Urban Studies 56(7): 1326-1346.

Robinson J (2011) Cities in a world of cities: The comparative gesture. International Journal of Urban and Regional Research 35(1): 1-23.

Robinson J (2015) "Arriving at" urban policies: The topological spaces of urban policy mobility. International Journal of Urban and Regional Research 39(4): 831-834.

Rodríguez-Pose A; Tomaney J and Klink J (2001) Local empowerment through economic restructuring in Brazil: The case of the greater ABC region. Geoforum 32: 459-469.

Sanfelici D (2013) Financeirização e a produção do espaço urbano no Brasil: uma contribuição ao debate. Eure 39(118): 27-46.

Savini F and Aalbers M (2016) The de-contextualisation of land use planning through financialisation: Urban redevelopment in Milan. European Urban and Regional Studies 23(4): 878-894.

Singer A (2015) Cutucando onças com varas curtas. Novos Estudos CEBRAP 102: 39-67.

Soja EW (2001) Postmetropolis: Critical studies of cities and regions. Malden, MA, USA; Oxford, UK; Melbourne, Australia and Berlin: Blackwell.

Souza VC de; Klink J and Denaldi R (2019) Planejamento reformista-progressista, instrumentos urbanísticos e a (re)produção do espaço em tempo de neoliberalização. Uma exploração a partir do caso de São Bernardo do Campo (São Paulo). Eure. Forthcoming. 
Swyngedouw E; Moulaert F and Rodriguez A (2002) Neoliberalization in Europe: Large scale urban development projects and the new urban policy. Antipode 34(3): 542-577.

Theurillat T and Vera-Büchel N (2016) Commentary: From capital lending to urban anchoring: The negotiated city. Urban Studies 53(7): 1509-1518.

Torrance MI (2008) Forging glocal governance? Urban infrastructures as networked financial products. International Journal of Urban and Regional Research 32(1): 1-21.

Weber R (2010) Selling city futures: The financialization of urban redevelopment policy. Economic Geography 86(3): 251-274.

Zwan vd N (2014) Making sense of financialization. Socio-Economic Review 12: 99-129. 


\section{References}

1 Wynne Godley (1997: 4) formulated the thesis of endogenous money in the following way: "Government can no more "control" stocks of either bank money or cash than a gardener can control the direction of a hosepipe by grabbing at the water jet".

2 The Report also worked creatively with Krugman's approach aimed at bringing space back into mainstream economics through the modelling of increasing returns to scale, scale economies and imperfect competition. These efforts generated what would become known as the New Economic Geography (Krugman, 1995). For a critical debate on the limits and potentials of New Economic Geography from the disciplinary perspective of geographers see Martin and Sunley (1996).

3 The discussion of the Pirelli case in Milan, Italy (see section 1.2), provides an emblematic example of the active involvement of industrial capital itself in the mobilization and financial leverage of its land assets (Kaika and Rugierro, 2016).

4 See, in that respect, Harvey's ideas on capital switching from the primary (productive) to the secondary (built environment) circuit. More recent work on the 2007 global mortgage crisis has shown that finance capital was also instrumental in the constitution of new interdependencies between the secondary and the tertiary circuit (related to Research and Development and the reproduction of life through private plans for complementary retirement and health services, for example). The real estate bubble in the USA triggered an increasing debt level of the more vulnerable segments of the population, who re-mortgaged their houses in order to contract complementary insurance services for health care and retirement (Aalbers, 2012).

5 Such as reversed mortgages, mortgages linked to life insurance services, micro-finance and consigned credit.

6 The French Regulation School was criticized in view of its somewhat functionalist interpretation of history and capitalist dynamism (Amin, 1994). More recent regulationist-inspired work on issues such as urban neoliberalization, state rescaling and restructuring (Jessop, 2000; Brenner, 2004, 2009; and Brenner and Theodore, 2002) has allowed for contingency in the investigation of the contradictory trajectories of state rollback and rollout in the demise of Fordist welfare regimes. For a similar discussion in the Brazilian scenario see Klink (2013).

7 In operational terms this means maximizing, in present values of the moment of decision-making, the sum of projected dividends and capital gains for shareholders (i.e. difference between acquisition and sale price of shares).

8 As will be discussed in section 1.2, the regulationist arguments structured around the transition from Fordist-Keynesian to property regimes also influenced the debates on financialization in cities, as exemplified by analyses on "asset price urbanism" in Ireland (Byrne, 2016), the emerging homeownership society in Spain and Madrid (López and Rodríguez, 2011) and the role of the developmental state in triggering speculative urbanism in Seoul (Korea) (Shin and Kim, 2016), among some of the examples.

9 Moreover, a full-fledged finance-led regime has hollowed out another pillar of the Keynesian-welfare regime, that is, monetary and fiscal policies aimed at full employment.

10 According to Lavoie (2006: 54), Post-Keynesian thought on monetary theory predates Keynes himself, considering that, already in the 1830 and 1840s, classical economists such as John Fullarton and Thomas Tooke developed ideas on endogenous money.

11 The concept of credit rationing is worked out by the difference between "notional demand" for credit (from both creditworthy clients and those who are not) and the "effective demand", which only includes potential creditworthy clients (Lavoie, 2006: 70).

12 Erturk et al. (2008) also recall that the centre-left, liberal-collectivist critique on the role of the rentier-financier goes back to earlier Marxist writing by Hilferding (1910) on founder's or promoter's profit from initial public offerings and subsequent trading of paper in secondary markets, aimed at maximizing financial profits (See also Chapter 
2). Its difference with the Marxian tradition, of course, was that liberal-collectivists accepted private property and wage labour but argued in favour of mechanisms of collective control aimed at stabilizing markets and guaranteeing social security.

13 Nevertheless, Erturk et al. (2008) and Froud et al. (2006) argue that the authors associated with principal-agency theory have had difficulties to empirically confirm the shareholder value dominance, for example, by showing consistently rising share prices and increasing dividends.

14 As reminded by these authors, ROCE is the ratio between returns and capital employed. Even considering that in specific sectors returns have increased, this has been accompanied by aggressive mergers and acquisition strategies coordinated by investment bankers, which effectively also raised the denominator of the ratio.

15 Nevertheless, as analyzed by Froud et al. (2006), performativity is never complete, considering that the 1987 crash generated discrepancies that were not predicted by the model. These authors also remind us, on the basis of Thrift's work (2001) on the "new economy" dot.com model, that the performativity of the Science, Technology and Knowledge economy was likewise incomplete, considering it was unable to perform on the unexpected bursts of the high-tech bubble in the early $2000 \mathrm{~s}$.

16 To be clear, we are paraphrasing Christopher's (2014a) dialectics structured around the notion "from Marx to markets and from markets back to Marx", considering that the other strands of political economy we have discussed earlier on (i.e. regulation theory and Post-Keynesianism) offer similar perspectives for complementarity with the concept of performativity.

17 Bayliss (2014) observes that these narratives are also driven by international funding agencies such as the World Bank and the International Finance Company.

18 In Chapter 5 we will discuss the experience of the listed mixed-capital water and sewage company of the state of São Paulo (SABESP), which has gradually adopted principles of corporatized shareholder governance.

19 In Chapter 7 we will develop a more detailed analysis on the rescaling and reframing of the capital market-austerity nexus and the emergence of financialized urban governance in Brazilian cities.

1 As also mentioned in the previous chapter, this critique had been raised in relation to French regulation school's reading of the transformation from Fordism to post-Fordism (Jessop, 2000).

2 For instance, Barnes' (1996) perspective on urban geography was aimed at the elaboration of what he called "post pre-fixed" theory.

3 Planning as a "praxis" is defined in terms of "the normal everyday attempts by social collectivities to develop and manage their life worlds, building, living, thinking" (LawYone, 2007: 318).

4 The research undertaken by authors such as Peck and Whiteside (2016) on austerity, restructuring and rescaling of the city-capital market nexus and its impacts on financialized urban governance represents an exception to this pattern in the literature.

5 In a way, our approach goes into the same direction as authors such as Dymski (2009: 439) when he recommends that: "those involved in understanding the urban problematic make deep contact with heterodox economists".

6 In the next chapter we will discuss specific examples of how commodity money was used in nineteenth-century Brazil under conditions of scarcity of gold and other forms of hard cash or liquidity. While coffee was instrumental as a means of payments, slaves represented a mechanism to store and preserve value. See also Costa (2012: 426).

7 In the next section we will work out in more detail the concept of financial profit for the urban context.

8 It is outside the scope of this book, but the creation of intermediary-continental scales for monetary policy design and implementation, as reflected in the experience of the European Central Bank and the creation of the euro, is another example of this 
continuous search for a more balanced articulation between states, scales and territory in a scenario of imperfect global monetary governance.

9 Neoclassical economics and finance theory only focuses on "standardized time", where well-functioning and competitive markets exist, with actors assuming risks that are strictly correlated to the fluctuations of individual investment portfolios in relation to a hypothetical (and known) market portfolio. This excludes systemic risks associated with market making. This assumption allows "normal economic science" to move away from the complexities that surround the social constitution of money, credit and finance, as well as their preservation in times of immanent collapse.

10 In relation to the constitution of financialization, we will analyze large urban redevelopment projects financed with securitized building rights (Chapter 4), the penetration of shareholder value premises in collaborative state-municipal water governance (Chapter 5), the mobilization of the state in the design and making of "market friendly" social housing finance systems (Chapter 6), and the reframing and restructuring of the city-capital market nexus in times of crisis and austerity (Chapter 7), among some of the examples discussed. With regard to financial crisis management, Chapter 3 discusses historical examples of how the state has recurrently absorbed the economic costs of financial bankruptcies as well as stabilization programs.

11 As remembered by Birch (2017), assets are not synonymous to commodities in the sense that the latter can also be traded in markets but do not generate a periodic income associated with their ownership. In a way, this is the difference between buying a CD in the record shop (commodity) or downloading the same music by paying a user charge to the company that owns the copyrights of the song or artist (asset).

12 In Chapter 5 we develop a somewhat similar argument for water pricing and the making of financialization in the context of Metropolitan São Paulo.

13 According to Lapavitsas (2013), net present value can be interpreted in terms of Marx's conceptualization of fictitious capital. This is particularly relevant when analyzing the role of the state in the making of financialization through its influences on Net Present Value calculations made by communities of financial and non-financial actors alike.

14 It should be observed that our notion of differential capitalization as one of the quantitative dimensions of the absorption of risk by the state in the making of urban financialization is related but more specific than Nitzan and Bichler's (2009) conception. The latter analyze differential capitalization in terms of the asymmetric power relations that are involved in the design and implementation of the capitalization formula, both in terms of the numerator (hype and exaggeration in the estimation of projected revenue streams) as well as in the interest rates that are used in the discounting procedure. For Nitzan and Bichler, the essence of differential capitalization is power.

15 The principle of financial leverage is a key element of modern finance theory and also contributes to problematize the supposed inherent contradiction between industry and finance, a misunderstanding that continues to hunt some of the literature on financialization. See also Chapter 1.

16 As mentioned by Lapavitsas (2013), Marx adopted the same assumption.

17 This is calculated as the difference in present value of two equivalent ad-infinitum income streams that are capitalized with different interest rates. In other words, this amounts to the difference between $\mathrm{R} \$ 500,000 / 4 \%=\mathrm{R} \$ 12.5$ million and $\mathrm{R} \$ 500,000 / 6 \%=\mathrm{R} \$ 8.3$ million.

18 This is different from projects effectively earning an internal rate of return that is higher than the cost of capital. The difference becomes essential at the turning point of economic cycles, when bubbles tend to burst.

19 There are additional costs. For instance, in order to avoid inflationary pressure from the inflow of dollars, national central banks sterilize/buy the additional dollars through the sale of domestic debt titles in the local market, which imply a higher interest burden. Moreover, domestic capitalists in the global south have actively explored the role of the 
dollar reserves as self-insurance. To be specific, they have effectively used the interest rate spreads to implement "carry trade", that is, borrow internationally at low rates and reinvest in domestic financial assets with higher yields. This has imposed additional tributes and opportunity costs and has increased the disparities within countries of the Global South.

20 Starting 2015, Quarter 2, the breakup of the times series for emerging and developing countries is no longer available.

21 As a matter of fact, Lapavitsas (2013) does distinguish between two broad segments within the Global South. The first comprises a set of countries that have gained a significant share in the export markets of manufactured goods to the US and Europe (China being the main example). The second group is composed of countries that export commodities, oil and unprocessed mineral products (including Russia and the Gulf countries). Nevertheless, this broad classification fails to recognize the significant differences within the Global South in respect to the direction of the flow of funds to the rest of the world.

22 The specific classification of the IMF for emerging markets and developing economies is the following. Commonwealth of independent states: Azerbaijan, Kazakhstan, Russia, Turkmenistan, Tajikistan and Uzbekistan. Emerging and developing Asia: Brunei Darussalam, Timor-Leste, Kiribati, Lao P.D.R., Marshall Islands, Mongolia, Papua New Guinea, Solomon Islands and Tuvalu. Latin America and the Caribbean: Bolivia, Brazil, Ecuador, Trinidad and Tobago, Venezuela, Argentina, Chile, Guyana, Paraguay, Peru, Suriname and Uruguay. Middle East, North Africa, Afghanistan and Pakistan: Algeria, Bahrain, Iran, Iraq, Kuwait, Libya, Oman, Qatar, Saudi Arabia, United Arab Emirates, Yemen, Afghanistan, Pakistan, Mauritania, Somalia and Sudan and SubSaharan Africa: Angola, Chad, Republic of Congo, Equatorial Guinea, Gabon, Nigeria, South Sudan, Burkina Faso, Burundi, Central African Republic, Democratic Republic of the Congo, Côte d'Ivoire, Eritrea, Guinea, Guinea-Bissau, Liberia, Malawi, Mali, Sierra Leone, South Africa, Zambia and Zimbabwe. The data have been collected from the IMF "World Economic Outlook 2019". Statistical Appendix. A14.

23 The trade deficit accumulated by less dynamic, smaller cities with big cities and metropolitan areas of the same national space economy leads to a net outflow of funds and wealth from the former to the later. In a way, this is similar to the flow of funds pattern that was prevailing among countries under the gold standard (considering that cities and metropolitan areas do not control exchange and monetary policies).

24 Table 2.3 shows that China's stock of international reserves has indeed been reduced very gradually during the period between 2011 and 2019 (a yearly reduction of $0.36 \%$ ).

25 Our argument was that there isn't.

26 Evidently, as will be seen in the case studies, profit-generating projects are not necessarily equivalent to equitable and/or sustainable projects.

1 Although it was prevailing until 1930, its gradual transformation had already been set in motion since the First World War, driven by the emergency substitution of interrupted imports as well as by successive balance of payment problems and exchange rate crises.

2 As a colony, these remittances were initially directed to the Portuguese crown. In a subsequent stage, profits were increasingly remitted to London as the emerging global financial centre.

3 This section is based on the work of Fundação Perseu Abramo (2019) and Costa (2012).

4 Formal independence was proclaimed in 1822, but the Portuguese court had been relocated to Brazil and the proclamation of the republic only occurred in 1889.

5 Somewhat different from São Paulo, the banking system of the capital city of Rio de Janeiro became specialized in the emission and management of state debt and government securities. 
6 The exchange rate stabilization mechanism of 1906 was approved by law (the so-called cash conversion mechanism or caixa de conversão) and would also prove essential to realize the government support to the coffee sector. Stabilization of the exchange rate was key in providing minimum price guarantees to domestic coffee producers. To be specific, considering that exporters receive international currency, a hypothetical appreciation of the Brazilian currency would threaten domestic debt repayment by coffee producers.

7 For a detailed conceptual and numerical discussion see also chapter 2. In the specific case under consideration, the dividends are capitalized with the relatively low (subsidized) interest rates that could be obtained in Brazil, generating a higher net present value and subsequent founder's profit by floating Brazilian companies in European stock exchanges.

8 This measure would also prove instrumental in avoiding that foreign banks would continue to use the domestic market as a privileged space of generating financial profits through gearing, thereby minimizing the need to mobilize foreign investment funds.

9 In addition to the broader objective of coordinating more closely monetary, credit and exchange rate policies, the need for a stricter regulation of German, Japanese and Italian banks also emerged in light of these countries' role as enemies in the Second World War.

10 It continues to perform a similar role under a slightly different name, that is, the National Bank for Economic and Social Development (Banco Nacional para o Desenvolvimento Econômico e Social).

11 A first best solution would be the elimination of inflation itself, which was only realized at the time of the Plano Real in 1994.

12 Currency boards imply reduced domestic discretionary power over monetary policy considering the fact that national currencies are pegged to key money such as the dollar. Brazil's Plano Real never went that far since it remained the scope for policy discretion over the exchange rate in light of international shocks, such as the one that occurred in 1998. Argentina, however, inserted the clause that pegged the exchange rate of the peso to the dollar into its constitution. This generated a dramatic scenario whereby domestic living conditions were gradually adjusted downwards according to the successive external shocks that affected the country during 1998-2001. It ultimately led to the December 2001 street riots and the resignation of president de la Rúa after the restrictions on people's ability to withdraw cash from banks (the Corralito in Spanish).

13 This section is a based on Klink and Denaldi (2014: 221-223).

14 Autonomous savings and credit schemes without state regulation and intervention had existed since 1910 .

15 Two lines of operations were targeted at rental and/or owner-occupied housing for members while a third introduced mortgages to external clients.

16 The distant housing estates that had initially been constructed without much infrastructure implied a subsequent rollout of infrastructure finance (Bolaffi, 1977).

17 Moreover, loan repayments were indexed on a yearly basis while monetary correction of outstanding balances occurred quarterly, thus generating additional implicit subsidies and financial deficits within the system.

18 FCVS, the literal translation being the "Fund aimed at compensating the variation in growth of salaries" (Fundo de Compensação de Variação Salarial). Estimates by the Ministry of Finance in 2009 amounted to a present value of debt of around R\$ 170 billion.

19 Depending on the original source of funds the coupon rate would be $3.12 \%$ or $6 \%$ plus inflation correction.

20 PROER stands for Programa de Estímulo à Reestruturação e ao Fortalecimento do Sistema Financeiro Nacional.

21 For a paradigmatic example of the influential international circulation of ideas on market-friendly housing finance see the international seminar, "Housing Finance in 
Emerging Markets: Policy and Regulatory Challenges", which was organized by the World Bank Group during March 10-13, 2003 in its head-office in Washington. It was explicitly targeted at officials working in the "old" developmental housing bank institutions in countries of the Global South, such as Brazil, India, Thailand and Indonesia.

22 The so-called Fundo de Garantia de Tempo de Serviço (FGTS, meaning Guarantee Fund Based on Service Time Contributions) would become the main source of lowincome housing finance.

23 Finally, $20 \%$ of all savings were to be deposited at the central bank, while $15 \%$ was to be held as a liquidity reserve.

24 Most of the system's initial operating experience was achieved in the commercial sector where a more stable and predictable cash flow profile provided a relatively superior basis for project-finance.

25 In January 2019, a minimum salary is R $\$ 998,00$, that is, 247,64 USD (exchange rate of $4.03(14 / 8 / 2019)$.

26 The "really existing" low-income market is composed of families earning up to three minimum salaries.

27 This is what Oliveira (1988) labelled a state-mediated generation of anti-value. More specifically, the state used the public fund to contribute to the formation of a social wage through the subsidization of housing and urban infrastructure, which were removed from the mechanism of capitalist reproduction and re-distributed to workers. As such, the welfare state was directly involved in the reduction of risk for households and labourers. See Chapter 2.

1 Section 4.2 and 4.3 are reprinted from the journal, Land Use Policy, Volume 69, Jeroen Klink and Lais Eleonora Maróstica Stroher, "The Making of Urban Financialization? An exploration of Brazilian urban partnership operations with building certificates", pages 521-526 (2017), with permission from Elsevier.

2 CEPAC means Certificado de Potencial Adicional de Construção (Additional Building Right Certificate).

3 In the words of one of the brokers we interviewed: "I think this mechanism of securitized building rights is wonderful business; it represents an emerging Brazil, bringing in the awareness and responsibilities regarding capital markets" (Interview no. 1, Broker, November 2016). Citation taken from Klink and Stroher (2017: 519).

4 Maleronka (2010: 129) analyzes that while Água Espraiada incorporated 1,400 hectares, the ZAC Paris Rive Gauche and Poblenau in Barcelona comprised 130 hectares.

5 The Curitiba scenarios were elaborated on the basis of $10 \%$ cost overruns.

6 Explanations for the agio in 2008 remain inconclusive, such as buyer errors predicting finalization of the UPO and individual efforts to speculate with CEPACs.

7 These values were also converted to 2013 .

8 For Faria Lima, for example, the initial emission on 26/5/2010 provided a price of $\mathrm{R} \$ 6,343.47$, while on $15 / 10 / 2015$ CEPACs were sold in the secondary market for $\mathrm{R} \$ 11,083.23$. (Data organized by the authors on the basis of prospectuses and interviews with CEPAC brokers.)

9 More specifically, national decree No 13, May the 10th of 2016 (Ministry for Cities).

10 Brookfield has signed a preliminary agreement to buy Odebrecht Ambiental for 1.7 billion USD.

11 Fusões e Aquisições. Brookfield avança com Lava Jato e 'pechinchas'. Available at: http://fusoesaquisicoes.blogspot.com.br/2017/01/brookfield-avanca-com-lava-jato-e. html. (Accessed 16 January 2017).

12 Lava Jato -Car Wash- is the name of the investigation undertaken by the National Public Prosecutor's Office and federal judges of possible bribes and corruption involving state companies such as Petrobras (active in oil, gas and refinery), development banks and contractors of public works. Among others, it generated the imprisonment of former president Lula Inácio da Silva, as well as the owners and several chief executive officers of contractor companies and state enterprises. 
13 The subsequent competitive bidding not only allows the original firms to participate but also envisages the possibility of compensation of the costs associated with the initial study.

14 Contractors were keen on increasing their leverage over the design of redevelopment projects in general, and risk sharing clauses in particular. See, for instance, the introduction to the project proposal that was developed for the Arco de Tiête redevelopment project by the contractor Odebrecht: "Defining the risk regarding costs and timing of the implementation of works as a responsibility of the private partner, the latter should be in the position to decide on the commercialization of building rights. To do the opposite would be to transform risk (probable event) into uncertainty (unpredictable event), putting private partners into a situation where they have no control" (Odebrecht et al., 2016: 2-3). See D'Almeida (2019) for a more detailed discussion on the Arco de Tiête project in the city administration of former mayor Fernando Haddad.

15 According to municipal Decree No 56.901/2016, providing guidelines for Urban Intervention Projects (PIUs).

16 The following discussion is based on D'Almeida (2019).

17 The plan allowed for floor area ratios of four (that is, building rights four times the size of the land area), accompanied by generous bonuses (additional building rights) in case developers followed certain municipal guidelines in terms of the use of façades and circulation area for pedestrians.

18 To be specific, municipal law 16.211/2015 was changed to law 16.703/2017.

19 The City Statute provides general guidelines on what is called "concerted urbanism", that is, "the cooperation between governments, private sector and Civil Society in the urbanization process, while attending to the social interest".

20 More particularly, municipal Law 14917/09, approved on May 7, 2009, regulates urbanistic concessions in the municipality of São Paulo.

1 Section 5.2, 5.3 and 5.4 are reprinted from the journal, Urban Studies, first online, Jeroen Klink; Vanessa Lucena Empinotti and Marcelo Aversa, "On contested water governance and the making of urban financialization: Exploring the case of Metropolitan São Paulo, Brazil”, pages 6-20 (2019), with permission from Sage.

2 For a reference on Greater São Paulo see Empinotti et al. (2018).

3 This challenge remains considering the presidential veto on the creation of a national fund for metropolitan areas when approving the Statute of the Metropolis.

4 This court ruling has generated uncertainty regarding the specific financial design and governance model that will be adopted. Consequently, congress even prepared a proposal for a constitutional amendment on metropolitan governance in 2014, which has not advanced.

5 Based on the files of process 08700.011091/2015-18 within CADE (CADE, 2018).

6 In August 2017, Law No 16.525/(September 15, 2017) created a public holding company that is capitalized through the transfer of SABESP's assets and, eventually, by other capital emissions and transfers.

7 Based on general price index FGV. Available at: www.ipeadata.gov.br/ExibeSerie. aspx?serid $=38390$ (accessed 1 February 2019$)$.

$8 \mathrm{R} \$ 3.66=1$ USD (as per 02/02/2019).

9 Margin squeezing is the reduction of the difference between the price of retail and the cost of wholesale water.

10 During 2007/08, Lyonnaise des Eaux was investigated for retail water margin squeeze in the province Ile de France.

11 CADE (2018). File 0132482.

12 CADE (2018). Nota técnica No 13/2017/CGAA3/SGA1/CADE.

13 CADE (2018). Nota técnica No 13/2017/CGAA3/SGA1/CADE: 12.

14 SEMASA's had requested access to SABESP's cash flow and accrual accounts, which was denied by CADE. 
15 The economic value of assets is calculated as the net present value of expected income flows, using the average cost of capital in the discounting procedure. With given revenues, a lower cost of capital increases SEMASA's economic value. The projections indicated that working capital costs would rise to $11 \%$ in 2022, while an IPO could lower SEMASA's net cost of capital to around $8 \%$.

16 The information is based on: Rocha R and Maia C (2019) Ação da SABESP volta a subir e bate recorde histórico na B3. Valor, 15 January.

1 At the time of the creation of phase I of MHML (April 2009), this amounted to $\mathrm{R} \$ 1,395$.

2 Among others, a group of 11 research teams from different universities organized around the "Network on Cities and Housing" in order to design and implement a collaborative evaluation study of the MHML program, which was financed by the Ministry of Science and Technology and the Ministry of Cities. The teams and the specific regions analyzed were: the Federal University of Pará (metropolitan region of Belém and the South-eastern part of the state of Pará); Federal University of Ceará (metropolitan region of Fortaleza); Federal University of Rio Grande do Norte (metropolitan region of Natal); Federal University of Minas Gerais (metropolitan region of Belo Horizonte); Institute for Urban and Regional Research and Planning (IPPUR) and Post-Graduate Program for Urbanism (PROURB) from the Federal University of Rio de Janeiro (metropolitan region of Rio de Janeiro); the Institute POLIS (metropolitan São Paulo); the PUC University of São Paulo (metropolitan São Paulo with specific work on the city of Osasco); LABCIDADES (Faculty of Architecture and Urbanism, University o São Paulo) (metropolitan regions of São Paulo and Campinas); University of São Paulo in the city of São Carlos and the PEABIRU Institute (metropolitan region of São Paulo) and University of São Paulo in the city of São Carlos (Administrative regions of São Carlos and Ribeirão Preto). The final results of these collaborative research efforts were organized and published by Amore et al. (2015), using a provocative title: "My House ... And the City? Evaluation of the Program My House My Life in six Brazilian States".

3 The abbreviation is derived from the first letters of the three economically more important cities, that is, Santo André, São Bernardo do Campo and São Caetano do Sul, respectively.

4 To be specific, in March 2016, after the impeachment of President Dilma Roussef and already in the midst of an economic and political crisis, the federal government nevertheless managed to launch MHML-phase III, with considerably more modest delivery targets and limited implementation progress at the time of writing. See also Table 6.3 with the main summary statistics on Phases I to III of the program.

5 As shown in Table 6.3, however, phase III of MHML insists in repeating the classical pattern of Brazilian social housing finance by not ex-ante matching the available subsidies, target groups and the overall reduction of the housing deficit.

6 This section is based on Klink et al. (2016).

7 This study was based on data that were made available by the Centro de Estudos da Metrópole (CEM, meaning Centre for Studies on the Metropolis), which provided access to the real estate information system from the Empresa Brasileira de Estudos do Patrimonio (EMBRAESP, meaning the Brazilian Company on Real Estate Studies). For the specific purposes of providing a general overview of the real estate dynamics in the region we have concentrated on the period until 2011. The reason is that, after that year, the statistical series provided no longer allows an analysis according to the size and capital structure of developers.

8 We follow the classification of Hoyler (2014). Small developers: an individual yearly revenue base smaller than $\mathrm{R} \$ 50$ million and having only one or two projects/ undertakings (representing 65.9\% of the overall number of firms); Medium-sized developers (making up 33.3\% of the total number of establishments), with revenue 
levels in between R\$ 50 million and R\$ 2 billion; and big developers $(0.8 \%$ of the overall number of companies), with developments between R $\$ 2$ and R $\$ 23$ billion.

9 Calculations were done on the basis of the General Price Index (IGP-DI) taken from the Fundação Getúlio Vargas (FGV). The annual geometric growth rate of this index during 2000-2010 was $9.64 \%$, which was used to transform historical nominal values into present values of 2011 .

10 It should be observed that the CEM-EMBRAESP database used here shows launch prices for new developments, which are not equivalent to the prices effectively charged for new developments.

11 To be specific, in many metropolitan regions (therefore including the $\mathrm{ABC}$ region), slum settlements are extremely dense. Therefore, upgrading operations frequently require partial relocation of the community and provision of alternative nearby housing units in order to guarantee the physical-technical-environmental sustainability of the remaining communities in slums. In the second phase of the program, the mayors succeeded in changing the operational guidelines of the program in order to facilitate the matching between slum upgrading and complementary provision of housing units.

12 All values were calculated in real prices in terms of the base year 2015.

13 In the last decade or so, this has been occurring in the older industrial corridors in São Bernardo do Campo (e.g. after the closure of the textile company Tognato), Santo André (in the Tamanduatei area around the São Paulo railway that connects São Paulo and the $\mathrm{ABC}$ region) and São Caetano do Sul (for instance, in the area of the Cerâmica neighbourhood). In the post-2006 scenario, the overheated real estate market increased the pressure to transform industrial areas to residential and mixed land uses.

14 As a matter of fact, before the creation of MHML, the private sector was rather reluctant to build and develop projects in ZEIS areas considering the perceived lack of financial feasibility. ZEIS were evaluated as a financial burden that required compensating subsidies. In all cities of the $\mathrm{ABC}$ region, the launch of MHML provided this compensation and triggered a significant development of social housing in ZEIS (Souza, 2018).

15 The following section is based on Arcanjo (2016) and Klink et al. (2016).

16 The same is true for the housing units bought without using credit, which is nevertheless a marginal phenomenon.

17 In present values of 2014 according to the general price index (IGPM).

18 In present values of 2014 according to the building construction index (INCC).

19 In present values of 2014 according to the general price index (IGPM).

20 The data on loan defaults and "subprime" housing on the balance sheets of banks were obtained from the financial newspaper Valor. Available at: www.valor.com.br/ financas/6211435/bancos-nao-conseguem-dar-vazao-imoveis-retomados. (Accessed July 12th, 2019).

21 Likewise, Acolin et al. (2019) provide data on delinquency rates for Target Group 1 projects in six metropolitan areas (Belo Horizonte, Fortaleza, Rio de Janeiro, Salvador, Baixada Santista/Santos and São Paulo). In spite of the high level of subsidy for these target groups, they find that $28 \%$ of beneficiaries had not made a payment for 90 days or more as of December 2015. The authors explore four hypotheses for this relatively high rate of delinquency, that is, the peripheral location of units, insufficient income to cover ongoing user costs in housing estates (infrastructure, service costs and so on), deficient management of default and delinquency (generating issues of moral hazard) and the presence of organized crime. On the basis of these findings, they recommend a subsidy design that takes into considering the location of units (that is, higher subsidies for units in better locations in order to reduce delinquency rates). For the specific case of the $\mathrm{ABC}$ region, however, we have relativized issues of peripheral localization.

1 In addition, in Chapter 1 we discussed specific Post-Keynesian literature on the relations between risk, urban governance and capital markets, according to which city governments would gradually move from stable hedge finance, to increasingly speculative 
Ponzi-type financial strategies in municipal markets for bonds and debentures. See Kirkpatrick (2016).

2 Approved by the National Monetary Council ruling № 162 in 1995.

3 More specifically, federal debt increased from R\$ 60.7 billion in July 1994 to R\$ 624.1 billion in December 2001. Forty-seven per cent of this increase, that is, R 297.7 billion, was due to re-financing municipal and state debts (Nascimento and Debus, 2001: 46).

4 The figures are taken from Costa (2012: 181-182). The values are converted according to the overvalued currency that was prevailing during the second half of the 1990s. This author also recalls that the extremely high interest rates prevailing after the Plano Real led to escalating costs associated with the delay in negotiations. For instance, if a re-finance agreement would have been signed two years earlier, the debt involved in the re-negotiation would be approximately half the amount.

5 As will be discussed subsequently, this clause would generate one of the loopholes utilized by companies such as $P B H$-Ativos.

6 This empirical section is based on a detailed analysis of the experience of the $\mathrm{PBH}$ Ativos $S / A$ company in the city of Belo Horizonte (state of Minas Gerais), using archival research, an investigation of the debenture contracts and the available literature on the case, particularly by authors such as Canettieri (2017) and Klink (2018). The contracts are open-access public data and available at: http://pbhativos.com.br/ transparencia/contratos-e-convenios/ (accessed: June 1-30, 2018).

7 Source: open source site from the company PBH-Ativos available at: http://pbhativos. com.br/a-pbh-ativos/quem-somos/ (accessed July 26, 2019).

8 According to article 2 from Law No 10.003, November 25, 2010, which created the company $\mathrm{PBH}$ Ativos $\mathrm{S} / \mathrm{A}$.

9 More specifically, by using an initial price range, the coordinating bank explores whether the demand, as revealed by potential investors, covers the financing requirement of the public sector. If investor demand is lower than the requirements for finance, the price that was initially proposed proved too high and needs to go through successive "trial and error" adjustments in order to match funding needs and investors demand.

10 This deficit of $\mathrm{R} \$ 70$ million reflects financial gains of $\mathrm{R} \$ 28.3$ million of the coordinating bank BTG Pactual Ltd, while the rest is internalized by PBH-Ativos itself as part of its overall cash flow management.

11 The specific experience of $P B H$-Ativos also indicates the importance of "transfer agents" (Baker and Temenos, 2015; McCann, 2011) in the circulation of experiences. In that sense, it is worthwhile to mention the role of Edson Ronaldo Nascimento (expresident of $P B H$-Ativos), who worked as a finance secretary in the states of Goías and Tocantins and in the federal district of Brasilia. He was also consultant to the IMF and senior staff of the Brazilian Ministry of Finance (CNACD, n.d.; Canettieri, 2017).

12 For instance, see the national newspaper coverage from Folha de São Paulo, on July 28, 2019, which was titled: "In an attempt to solve fiscal crisis, seventeen states prepare privatizations". Available at: www.folha.uol.com.br/mercado/2019/07/na-tentativa-desuperar-crise-fiscal-17-estados-preparam-privatizacoes.shtml (accessed July 28th, 2019).

1 As discussed in Chapter 2, a political economy of valuation is concerned with the social power structures and conflicts involved in the circulation of norms and conventions that are used in the pricing and valuing of assets. It avoids falling into the methodological trap of some of the work of performativity in terms of doing "the dirty work" and naturalizing neo-classical economics. See also: Christophers (2014).

Aalbers MB (ed.) (2012) Subprime cities: The political economy of mortgage markets. Oxford: Wiley Blackwell.

Aalbers MB (2019) Financial geographies of real estate and the city: A literature review. In: Financial geography working paper series. ISSN 2515-0111. Leuven: University of Leuven. 
Aalbers MB and Christophers B (2014) Centring housing in political economy. Housing, Theory and Society 31(4): 373-394.

Aglietta M (2010) Shareholder value and corporate governance: Some tricky questions. Economy and Society 29(1): 146-159.

Aglietta M (2018) Money: 5,000 years of debt and power. London and New York: Verso.

Alonso W (1964) Location and land use. Cambridge, MA: Harvard University Press.

Amin A (1994) Post-Fordism: A reader. Oxford: Blackwell.

Arrighi G (1994) The long twentieth century: Money, power and the origins of our times. London: Verso.

Ashton P; Doussard M and Weber R (2016) Reconstituting the state: City powers and exposures in Chicago's infrastructure leases. Urban Studies 53(7): 1384-1400.

Aversa M; Empinotti V and Klink J (2018) Água: mercadoria, bem comum ou direito? Algumas contradições na implementação da política pública de direitos humanos de acesso à água e ao saneamento. Waterlat-Gobacit Network Working Papers. Thematic Area Series-TA3 5(3): 31-52.

Bakker K (2007) The "commons" versus the "commodity": Alter-globalization, antiprivatization and the human right to water in the global South. Antipode 39(3): 430-455.

Bakker K (2013) Neoliberal versus postneoliberal water: Geographies of privatization and resistance. Annals of the Association of American Geographies 103(2): 253-260.

Bakker K; Kooy M; Shofiani NE and Martijn EJ (2008) Governance failure: Rethinking the institutional dimensions of urban water supply to poor households. World Development 36(10): 1891-1915.

Baran PA and Sweezy PM (1966) Monopoly capital. New York: Monthly Review Press.

Bayliss K (2014) The financialization of water. Review of Radical Political Economics 46(3): 292-307.

Berle AA and Means GC (1932) The modern corporation and private property. Revised Edition 1968. New York: Harcourt, Brace and World, Inc.

Berndt C and Boeckler M (2009) Geographies of circulation and exchange: Construction of markets. Progress in Human Geography 33(4): 535-551.

Bielschowsky R (1988) Pensamento econômico brasileiro. O ciclo ideológico do desenvolvimentismo. Rio de Janeiro: Contraponto.

Black F and Scholes M (1973) The pricing of options and corporate liabilities. Journal of Political Economy 81(3): 637-654.

Blanchard OJ (1980) The monetary mechanism in the light of rational expectations. In: Fischer F (ed.) Rational expectations and economic policy. Chicago: University of Chicago Press, pp. 75-116.

Block F (2016) Introduction to the special issue: The contradictory logics of financialization: Bringing together Hyman Minsky and Karl Polanyi. Politics \& Society 44(1): $3-13$.

Boag G and McDonald DA (2010) A critical review of public-public partnerships in water services. Water Alternatives 3(1): 1-25.

Botein H and Heidkamp CP (2013) Tax lien sales as local neoliberal governance strategy: The case of Waterbury, Connecticut. Local Economy 28(5): 488-498.

Boyer R (2000a) Is a finance-led growth regime a viable alternative to Fordism? A preliminary analysis. Economy and Society 29(1): 111-145.

Boyer R (2000b) The political in the era of globalization and finance: Focus on some Régulation School Research. International Journal of Urban and Regional Research 24(2): 274-322.

Boyer R (2009) A Teoria da Regulação. Os Fundamentos. São Paulo: Estação Liberdade. 
Braudel F (1982) Civilization and capitalism, 15th-18th century: The wheels of commerce. Translated by Sian Reynolds. Berkeley: University of California Press.

Brenner N (2004) New state spaces: Urban governance and the rescaling of statehood. Oxford: Oxford University Press.

Brenner N (2009) Open questions on state rescaling. Cambridge Journal of Regions, Economy and Society 2: 123-139.

Brenner N and Theodore N (2002) Spaces of neoliberalism: Urban restructuring in Western Europe and North America. Oxford: Blackwell.

Bresnihan P (2016) The biofinancialization of Irish Water: New advances in the neoliberalization of vital services. Utilities Policies 40: 115-124.

Britto AL and Rezende SC (2017) A política pública para os serviços urbanos de abastecimento de água e esgotamento sanitário no Brasil: financeirização, mercantilizacão e perspectivas de resistência. Cadernos Metrópole 19(39): 557-581.

Brueckner JK (2001) Tax increment financing: A theoretical inquiry. Journal of Public Economics 81(2): 321-343.

Byrne M (2016) "Asset price urbanism" and financialization after the crisis: Ireland's National Asset Management Agency. International Journal of Urban and Regional Research 40(1): 31-45.

Callon M (1998) Introduction: The embeddedness of economic markets in economics. In: Callon M (ed.) The law of the markets. Oxford: Blackwell.

Canettieri T (2017) A produção capitalista do espaço e a gestão empresarial da política urbana. Revista brasileira de estudos urbanos e regionais 19(3): 513-529.

Charnock G; Purcell TF and Ribera-Fumaz R (2014) City of rents: The limits to the Barcelona model of urban competitiveness. International Journal of Urban and Regional Research 38(1): 198-217.

Chesnais F (ed.) (1996) La mondialisation financière: Genèse, enjeux et coûts. Paris: Syros. Chiapello E (2015) Financialisation of valuation. Hum Studies 38: 13-35.

Christophers B (2014a) From Marx to market and back again: Performing the economy. Antipode 57(1): 12-20.

Christophers B (2014b) Wild dragons in the city: Urban political economy, affordable housing development and the performative world-making of economic models. International Journal of Urban and Regional Research 38(1): 79-97.

Christophers B (2015) From financialization to finance: For "de-financialization". Dialogues in Human Geography 5(2): 229-232.

Christophers B (2017) The state and financialization of public land in the United Kingdom. Antipode 49(1): 62-85.

Clarke DB and Bradford MG (1998) Public and private consumption and the city. Urban Studies 35(5/6): 865-888.

Coase RH (1960) The problem of social cost. The Journal of Law \& Economics 3: 1-44.

Crosby N and Henneberry J (2016) Financialization, the valuation of investment property and the urban built environment in the UK. Urban Studies 53(7): 1424-1441.

Deruytter L and Derudder B (2019) Keeping financialization under the radar: Brussels Airport, Macquarie Bank and the Belgian politics of privatized infrastructure. Urban Studies 56(7): 1347-1367.

DiPasquale D and Wheaton W (1996) Urban economics and real estate markets. Upper Saddle River, NJ: Prentice Hall.

Eckhard H; Dodig N and Budyldina N (2014) Financial, economic and social systems: French regulation school, social structures of accumulation and post-Keynesian 
approaches compared. Working Paper No. 134. Institute for International Political Economy, Berlin.

Erturk I; Froud J; Johal S; Leaver A and Williams K (2008) Financialization at work: Key Texts and Commentaries. London and New York: Routledge.

Fama E (1970) Efficient capital markets: A review of theory and empirical work. Journal of Finance 25(2): 383-417.

Faulhaber GR and Baumol WJ (1988) Economists as innovators: Practical products of theoretical research. Journal of Economic Literature 26(2): 577-600.

Fields D (2014) Contesting the financialization of urban space: Community organizations and the struggle to preserve affordable rental housing in New York City. Journal of Urban Affairs 37(2): 144-165.

Fix M (2007) São Paulo Cidade Global: Fundamentos financeiros de uma miragem. São Paulo: Boitempo.

Friedman M (1968) The role of monetary policy. American Economic Review 58(1): 1-17.

Froud J; Haslam C; Johal S and Williams K (2001) Financialization and the coupon pool. Gestão \& Produção 8(3): 271-288.

Froud J; Johal S; Leaver A and Williams K (2006) Financialization and strategy: Narrative and numbers. London and New York: Routledge.

Godley W (1997) Macroeconomics without equilibrium or disequilibrium. Working Paper No. 205. The Levy Economics Institute, Annadale-on-Hudson, NY.

Gotham K (2009) Creating liquidity out of spatial fixity: The secondary circuit of capital and the subprime mortgage crisis. International Journal of Urban and Regional Research 33(2): 355-371.

Graham S and Marvin S (2001) Splintering urbanism: Networked infrastructures, technological mobilities and the urban condition. London and New York: Routledge.

Granovetter M (1985) Economic action and social structure: The problem of embeddedness. American Journal of Sociology 91: 481-510.

Guironnet A; Attuyer K and Halbert L (2016) Building cities on financial assets: The financialization of property markets and its implications for city governments in the Paris city region. Urban Studies 53(7): 1442-1464.

Guironnet A and Halbert L (2015) Urban development projects, financial markets, and investors: A research note. Chairville: École des Ponts Paritech.

Guy S; Henneberry J and Rowley S (2002) Development cultures and urban regeneration. Urban Studies 39(7): 1181-1196.

Haila A (1988) Land as a financial asset: The theory of urban rent as a mirror of economic transformation. Antipode 20(2): 79-100.

Haila A (2016) Urban land rent: Singapore as a property state. West Sussex: WileyBlackwell.

Halbert L and Attuyer K (2016) Introduction: The financialisation of urban production: Conditions, mediations and transformations. Urban Studies 53(7): 1347-1361.

Hicks J (1974) The crisis in Keynesian Economics. Oxford: Basil Blackwell.

Hildyard N (2016) Licensed larceny. Manchester: Manchester University Press.

Hilferding R (1910) Finance capital. London: Routledge \& Kegan Paul (1981 Edition).

Hall S (2010) Geographies of money and finance I: Cultural economy, politics and place. Progress in Human Geography 35(2): 234-245.

Harcourt GC (2006) The structure of post-Keynesian economics: The core contributions of the pioneers. Cambridge: Cambridge University Press. 
Harvey D (1989) From managerialism to entrepreneurialsm: The transformation in urban governance in late capitalism. Geografiska Annaler: Series B, Human Geography 71(1): $3-17$.

Harvey D (2009) Assessments: Reshaping economic geography: The world development report 2009. Development and Change 40(6): 1269-1277.

Harvey D (2013) Os Limites do Capital. Translated by Magda Lopes. São Paulo: Boitempo.

Helleiner E (1994) States and the re-emergence of global finance: From Bretton Woods to the 1990s. Ithaca and London: Cornell University Press.

Henneberry J and Roberts C (2008) Calculated inequality? Portfolio benchmarking and regional office property investment in the UK. Urban Studies 45(5\&6): 1217-1241.

Henrikson LF (2009) Are financial markets embedded in economics rather than society? A critical review of the performativity thesis. DIIS Working Paper. Danish Institute for International Studies, Copenhagen.

Jensen M and Meckling W (1976) Theory of the firm: Managerial behaviour, agency costs and ownership structure. Journal of Financial Economics 3(4): 305-360.

Jessop B (2000) The crisis of the national spatio-temporal fix and the tendential ecological dominance of globalizing capital. International Journal of Urban and Regional Research 24(2): 323-360.

Johnson B (2016) Atlantic City takeover plan moves forward despite uproar. NJ.com, 10 March. Available at: https://www.nj.com/politics/2016/03/atlantic_city_takeover_plan_ moves_forward_despite.html (accessed 2 December 2019).

Kaika M and Rugierro L (2016) Land financialization as a "lived" process: The transformation of Milan's Bicocca by Pirelli. European Urban and Regional Studies 23(1): 3-22.

Kaldor N (1985) Economics without equilibrium. Armonk, NY: ME Sharpe.

Kalecki M (1971) Selected essays on the dynamics of the capitalist economy. Cambridge: Cambridge University Press.

Keynes JM (1930) A treatise on money. 2 vols. London: Macmillan.

Keynes JM (1937) The "ex-ante" theory of the rate of interest. Economic Journal 47: 663-669.

Kirkpatrick LO (2016) The new urban fiscal crisis: Finance, democracy, and municipal debt. Politics \& Society 44(1): 45-80.

Klink J (2013) The hollowing out of Brazilian metropolitan governance as we know it: Restructuring and rescaling the developmental state in metropolitan space. Antipode 46(3): 629-649.

Klink J and Denaldi R (2014) On financialization and state spatial fixes in Brazil: A geographical and historical interpretation of the housing program My House My Life. Habitat International 44: 220-226.

Klink J; Empinotti V and Aversa M (2019) On contested water governance and the making of urban financialization: Exploring the case of metropolitan São Paulo, Brazil. Urban Studies. Online First. Forthcoming.

Klink J and Stroher L (2017) The making of urban financialization? An exploration of Brazilian urban partnership operations with building certificates. Land Use Policy 69: 519-528.

Krugman P (1995) Development, geography and economic theory. Cambridge, MA: The MIT Press.

Langley P (2004) In the eye of "the perfect storm": The final salary pensions crisis and the financialisation of anglo-American capitalism. New Political Economy 9(4): 539-538.

Lapavitsas C (2013) Profiting without producing: How finance exploits all of us. London and New York: Verso. 
Latour B (2005) Reassembling the social: An introduction to actor-network theory. Oxford: Oxford University Press.

Lavoie M (2006) Introduction to Post-Keynesian economics. New York: Palgrave MacMillan.

Lazonick W and O'Sullivan M (2000) Maximizing shareholder value: A new ideology for corporate governance. Economy and Society 29(1): 13-35.

Lipietz A (1987) Mirages and miracles: Crisis in global Fordism. London: Verso.

López I and Rodríguez E (2011) The Spanish model. New Left Review 69: 5-29.

MacKenzie D (2005) An engine, not a camera: How financial models shape markets. Cambridge, MA: The MIT Press.

March H and Purcell T (2014) The muddy waters of financialization and new accumulation strategies in the global water industry: The case of AGBAR. Geoforum 53: 11-20.

Martin R (2002) The financialization of daily life. Philadelphia: Temple University Press.

Martin R and Sunley P (1996) Paul Krugman's geographical economics and its implications for regional development theory: A critical assessment. Economic Geography 72(3): 259-292.

McCann E (2011) Urban policy mobilities and global circuits of knowledge: Toward a research agenda. Annals of the Association of American Geographers 101(1): 107-130.

Minsky HP (1981) Can "it" happen again? Essays on instability and finance. Armonk, NY: ME Sharpe.

Mosciaro M and Pereira A (2019) Reinforcing uneven development: The financialization of urban redevelopment projects. Urban Studies. Online First. Available at: https://doi. org/10.1177/004209801982942 (Accessed 1 April 2019).

Moulaert F (2005) Institutional economics and planning theory: A partnership between ostriches? Planning Theory 4(1): 21-32.

Muth R (1969) Cities and housing. Chicago: University of Chicago Press.

Newborne P and Mason N (2012) The private sector's contribution to water management: Re-examining corporate purposes and company roles. Water Alternatives 5(3): 603-618.

Nitzan J and Bichler S (2009) Capital as power: A study of order and creorder. London and New York: Routledge.

North D (1990) Institutions, institutional change and economic performance. Cambridge: Cambridge University Press.

O'Neill P (2018) The financialisation of urban infrastructure: A framework of analysis. Urban Studies. Online First. Available at: https://doi.org/10.1177\%2F0042098017751983 (Accessed 21 September 2018).

Pacewicz J (2013) Tax increment financing, economic development professionals and the financialization of urban politics. Socio-Economic Review 11: 413-440.

Pacewicz J (2016) The city as a fiscal derivative: Financialization, urban development, and the politics of earmarking. City \& Community 15(3): 264-288.

Paulani LM (1991) Do conceito de dinheiro e do dinheiro como conceito. Tese de Doutorado. Faculdade de Economia, Administração e Contabilidade da Universidade de São Paulo, São Paulo.

Paulani LM (2011) A inserção da economia brasileira no cenário mundial: uma reflexão sobre o papel do Estado e sobre a situação atual real à luz da história. In: Logros e Retos del Brasil Contemporâneo. Cidade de México, México, 24 a 26 de Agosto de 2011. UNAM.

Peck J (2017a) Transatlantic city, part 1: Conjuntural urbanism. Urban Studies 54(1): 4-30. Peck J (2017b) Transatlantic city, part 2: Late entrepreneurialism. Urban Studies 54(2): 327-363. 
Peck J and Whiteside H (2016) Financializing Detroit. Economic Geography 92(3): 235-268.

Polanyi K (1997) The great transformation: The political and economic origins of our time. Boston, MA: Beacon Press.

Pryke M and Allen J (2017) Financialising urban water infrastructure: Extracting local value, distributing value globally. Urban Studies. Online First: 1-21. Available at: https://doi.org/10.1177/0042098017742288 (Accessed 2 April 2019).

Robinson J (2006) Ordinary cities: Between modernity and development. London: Routledge.

Rolnik R (2018) Urban warfare: Housing under the empire of finance. London: Verso.

Rooyen vC and Hall D (2007) Public is as private Does: The confused case of Rand Water in South Africa. Municipal Services Project. Occasional Paper Series No. 15. Logo Printers, Cape Town.

Rouanet H and Halbert L (2016) Leveraging finance capital: Urban change and selfempowerment of real estate developers in India. Urban Studies 53(7): 1401-1423.

Rutland T (2010) The financialization of urban redevelopment. Geography Compass 4(8): $1167-1178$.

Sandroni P (2010) A new financial instrument of value capture in São Paulo: Certificates of additional construction potential. In: Ingram GK and Hong YH (eds.) Municipal revenues and land policies. Cambridge, MA: Lincoln Institute of Land Policy, pp. 218-236.

Sanfelici D (2013) Financeirização e a produção do espaço urbano no Brasil: uma Contribuição ao debate. Eure 39(118): 27-46.

Savini F and Aalbers M (2016) The de-contextualisation of land use planning through financialisation: Urban redevelopment in Milan. European Urban and Regional Studies 23(4): 878-894.

Shin HB and Kim SH (2016) The developmental state, speculative urbanisation and the politics of displacement in gentrifying Seoul. Urban Studies 53(3): 540-559.

Steindl J (1952) Maturity and stagnation in American capitalism. Oxford: Basil Blackwell.

Swyngedouw E; Moulaert F and Rodriguez A (2002) Neoliberalization in Europe: Large scale urban development projects and the new urban policy. Antipode 34(3): 542-577.

Tawney RH (1923) The acquisitive society. London: Bell and Sons.

Theurillat T and Vera-Büchel N (2016) Commentary: From capital lending to urban anchoring: The negotiated city. Urban Studies 53(7): 1509-1518.

Thrift N (2000) Pandora's box? Cultural geographies of economies. In: Clark G; Feldman $\mathrm{M}$ and Gertler M (eds.) The Oxford handbook of economic geography. Oxford: Oxford University Press, pp. 689-704.

Thrift N (2001) "It's the romance not the finance that makes the business worth pursuing": Disclosing a new market culture. Economy and Society 30(4): 412-432.

Torrance MI (2008) Forging glocal governance? Urban infrastructures as networked financial products. International Journal of Urban and Regional Research 32(1): 1-21.

Ülgen F (2014) Financialized capitalism and the irrelevance of self-regulation: A Minskyian analysis of systemic viability. In: 12th International Post Keynesian Conference, Kansas City, Missouri, USA, September 25-28.

Van Loon J and Aalbers MB (2017) How real estate became "just another asset class": The financialization of the investment strategies of Dutch institutional investors. European Planning Studies 25(2): 221-240.

Van Loon J; Oosterlynck S and Aalbers MB (2018) Governing urban development in the low countries: From managerialism to entrepreneurialism and financialization. 
European Urban and Regional Studies. Online First. Available at: https://oi.org/ 10.1177/0969776418798673 (Accessed 1 April 2019).

Watson V (2016) Shifting approaches to planning theory: Global North and South. Urban Planning 1(4): 32-41.

Weber (2010) Selling city futures: The financialization of urban redevelopment policy. Economic Geography 86(3): 251-274.

Weber (2015) From boom to bubble: How finance built the new Chicago. Chicago and London: The University of Chicago Press.

Whiteside H (2019) Advanced perspectives on financialised urban infrastructures. Urban Studies. Online First. Available at: https://doi.org/10.1177/0042098019826022 (Accessed 3 April 2019).

Wijburg G (2018) Privatised Keynesianism and the state-enhanced diversification of credit: The case of the French housing market. International Journal of Housing Policy. Online First. Available at: www.tandfonline.com/doi/full/10.1080/19491247.2017.1397 926 (Accessed 5 April 2019).

Williamson O (1985) The economic institutions of capitalism. New York: The Free Press.

World Bank (2009) World development report 2009: Reshaping economic geography. Washington, DC: The World Bank.

van der Zwan N (2014) Making sense of financialization. Socio-Economic Review 12: 99-129.

Aglietta M (2018) Money: 5,000 years of debt and power. London and New York: Verso.

Barnes TJ (1996) Logics of dislocation: Models, metaphors, and meanings of economic space. New York and London: The Guilford Press.

Bielschowsky R (1988) Pensamento econômico brasileiro. O ciclo ideológico do desenvolvimentismo. Rio de Janeiro: Contraponto.

Birch K (2017) Rethinking value in the bio-economy: Finance, assetization, and the management of value. Science, Technology, \& Human Values 42(3): 460-490.

Black F and Scholes M (1973) The pricing of options and corporate liabilities. Journal of Political Economy 81(3): 637-654.

Brenner N (2000) The urban question as a scale question: Reflections on Henri Lefebvre, urban theory and the politics of scale. International Journal of Urban and Regional Research 24(2): 361-378.

Brenner N (2004) New state spaces: Urban governance and the rescaling of statehood. Oxford: Oxford University Press.

Brenner N and Theodore N (2002) Spaces of neoliberalism: Urban restructuring in Western Europe and North America. Oxford: Blackwell.

Brenner N; Peck J and Theodore N (2010) Variegated neoliberalization: Geographies, modalities and pathways. Global Networks 10(2): 182-222.

Brown JC and Purcell M (2004) There is nothing inherent about scale: Political ecology, the local trap and the politics of development in the Brazilian Amazon. Geoforum 36: 607-624.

Castells M (1977) The urban question. London: Edward Arnold.

Christophers B (2018) Risking value theory in the political economy of finance and nature. Progress in Human Geography 42(3): 330-349.

Costa FN da (2012) Brasil dos Bancos. São Paulo: Editora da Universidade de São Paulo.

Dymski GA (1998) "Economia de bolha" e crise financeira no Leste Asiático e na California: uma perpectiva espacializada de Minsky. Economia e Sociedade, Campinas 11: $73-116$. 
Dymski GA (2009) Afterword: Mortgage markets and the urban problematic in the global transition. International Journal of Urban and Regional Research 33(2): 427-442.

Faulhaber GR and Baumol WJ (1988) Economists as innovators: Practical products of theoretical research. Journal of Economic Literature 26(2): 577-600.

Fiori JL (1997) Os moedeiros falsos. Petropolis: Vozes.

Greco E (2015) Value or rent? A discussion of the research protocol from a political economy perspective. LCSV Working Paper Series No. 8. Leverhulme Centre for the Study of Value, the University of Manchester, Manchester.

Harvey D (1973) Social justice and the city. Baltimore: John Hopkins University.

Harvey D (1982) The limits to capital. Oxford: Basil Blackwell and Chicago: University of Chicago Press.

Harvey D (2014) Cidades Rebeldes. Do Direito à Cidade à Revolução Urbana. São Paulo: Martins Fontes.

Helleiner E (1994) States and the re-emergence of global finance: From Bretton Woods to the 1990s. Ithaca and London: Cornell University Press.

Hilferding R (1910) Finance capital. London: Routledge \& Kegan Paul (1981 Edition).

Jessop B (2000) The crisis of the national spatio-temporal fix and the tendential ecological dominance of globalizing capitalism. International Journal of Urban and Regional Research 24(2): 323-360.

Jessop B (2015) Hard cash, easy credit, fictitious capital: Critical reflections on money as a fetishized social relation. Finance and Society 1(1): 20-37.

Klink J (2014) The hollowing out of Brazilian metropolitan governance as we know it: Restructuring and rescaling the developmental state in metropolitan space. Antipode 46(3): 629-649.

Klink J and Denaldi R (2014) On financialization and state spatial fixes in Brazil: A geographical and historical interpretation of the housing program My House My Life. Habitat International 44: 220-226.

Lapavitsas C (2013) Profiting without producing: How finance exploits all of us. London and New York: Verso.

Law-Yone H (2007) Another planning theory? Rewriting the meta-narrative. Planning Theory 6(3): 315-326.

Lefebvre H (1974) La production de l'espace. Paris: Anthropos.

Maricato E (1996) Metrópole na Periferia do Capitalismo: Ilegalidade, Desigualdade e Violência. São Paulo: Hucitec.

Markowitz HM (1959) Portfolio selection: Efficient diversification of investments. New Haven: Yale University Press.

Marx K (1967) Capital. Vol. 1, Third Edition. London: Lawrence and Wishart (1862-1863).

Massey D (2007) World city. Cambridge: Polity Press.

Moulaert F (2005) Institutional economics and planning theory: A partnership between ostriches? Planning Theory 4(1): 21-31.

Nitzan J and Bichler S (2009) Capital as power. A study of order and creorder. London and New York: Routledge.

North D (1990) Institutions, institutional change and economic performance. Cambridge: Cambridge University Press.

Oliveira F de (1988) O surgimento do Antivalor. Capital, força de trabalho e fundo público. Novos Estudos 22: 8-28.

Paulani LM (2011) A inserção da economia brasileira no cenário mundial: uma reflexão sobre o papel do Estado e sobre a situação atual real à luz da história. In: Logros e Retos 
del Brasil Contemporâneo. Cidade de México, México, 24 a 26 de Agosto de 2011. UNAM.

Peck J (2017a) Transatlantic city, part 1: Conjunctural urbanism. Urban Studies 54(1): 4-30.

Peck J (2017b) Transatlantic city, part 2: Late entrepreneurialism. Urban Studies 54(2): 327-363.

Peck J (2018) Teoria Urbana e Geografia Econômica: para além da comparação? In: Brandão CA; Fernández VR and Ribeiro LC de Queiroz (eds.) Escalas espaciais, reescalonamentos e estatalidades: lições e desafios para América Latina. Rio de Janeiro: Letra Capital: Observatório das Metrópoles, pp. 167-222.

Peck J and Whiteside H (2016) Financializing Detroit. Economic Geography 92(3): 235-268.

Pryke M and Allen J (2017) Financialising urban water infrastructure: Extracting local value, distributing value globally. Urban Studies 56(7): 1326-1346.

Purcell TF; Loftus A and March H (2019) Value-rent-finance. Progress in Human Geography. Online First: 1-20. Available at: https://journals.sagepub.com/doi/10.1177/0309 132519838064 (Accessed 5 May 2019).

Robinson J (2011a) Cities in a world of cities: The comparative gesture. International Journal of Urban and Regional Research 35(1): 1-23.

Robinson J (2011b) The travels of urban neoliberalism: Taking stock of the internationalization of urban theory. Urban Geography 32(8): 1087-1109.

Royer L (2014) Financeirização da Política Habitacional: Limites e Perspectivas. 1st Edition. São Paulo: Annablume.

Savini F and Aalbers MB (2016) The de-contextualization of land use planning through financialization: Urban redevelopment in Milan. European Urban and Regional Studies 23(4): 878-894.

Sanfelici D and Halbert L (2018) Financial market actors as urban policy makers: The case of real estate investment trusts in Brazil. Urban Geography. Online First. Available at: www.tandfonline.com/doi/full/10.1080/02723638.2018.1500246 (Accessed 5 May 2019).

Soja EW (1989) Postmodern geographies: The reassertion of space in critical social theory. London: Verso.

Stiglitz JE (2007) Making globalization work. New York and London: WW Norton and Company.

Swyngedouw E (1997) Neither global nor local: "Glocalization" and the politics of scale. In: Cox KR (ed.) Spaces of globalization: Reasserting the power of the local. New York and London: The Guilford Press, pp. 115-136.

Tavares M de C (1999) Império, Território e dinheiro. In: Fior JL (ed.) Estados e Moedas no desenvolvimento das nações. Petrópolis, RJ: Vozes, pp. 449-489.

Theurillat T and Vera-Büchel N (2016) Commentary: From capital lending to urban anchoring: The negotiated city. Urban Studies 53(7): 1509-1518.

Torrance MI (2009) The rise of a global infrastructure market through relational investing. Economic Geography 85(1): 75-97.

Villaça F (1999) Uma contribuição para a história do planejamento urbano no Brasil. In: Deák C and Schiffer SR (eds.) O processo de urbanização no Brasil. São Paulo: Editora da Universidade de São Paulo, pp. 169-244.

Aglietta M (2018) Money: 5,000 years of debt and power. London and New York: Verso. Araújo TB de (1999) Por uma política nacional de desenvolvimento regiona. Revista economica do Nordeste 30(2): 1-30. 
Arretche MT (1996) Desarticulação do BNH e autonomização da política habitacional. In: Affonso R de BA and Silva PLB (eds.) Descentralização e políticas sociais. São Paulo: FUNDAP, pp. 107-138.

Bielschowsky R (1988) Pensamento econômico brasileiro. O ciclo ideológico do desenvolvimentismo. Rio de Janeiro: Contraponto.

Bolaffi G (1977) A casa das ilusões perdidas: aspectos sócio-econômicos do Plano Nacional de Habitação. São Paulo: Brasiliense/CEBRAP.

Bonduki N (1998) Origens da habitação social no Brasil. São Paulo: Estação Liberdade.

Brasil (2010) Plano Nacional de Habitação. Brasília: Ministério das Cidades.

Brenner N and Elden S (eds.) (2009) State, space, world: Selected essays. Henri Lefebvre. Translated by Gerald Moore; Neil Brenner and Stuart Elden. Minneapolis: The University of Minnesota Press.

Cagnin RF (2012) A Evolução do financiamento habitacional no Brasil entre 2005 e 2011 e o desempenho dos novos instrumentos financeiros. Boletim de Economia 11(1): 15-32.

Campos PHP (2012) A ditadura dos empreiteiros. As empresas nacionais de construção pesada, suas formas associativas e o Estado ditatorial brasileiro, 1964-1985. Tese de Doutorado. Universidade Federal Fluminense, Instituto de Ciências Humanas e Filosofia, Departamento de História, Niterói.

Cano W (1998) Desequilíbrios regionais e concentração industrial no Brasil, 1930-1995. Campinas: Instituto de Economia da UNICAMP.

Costa FN da (2012) Brasil dos bancos. São Paulo: EDUSP.

Dymski GA (1998) "Economia de bolha" e crise financeira no Leste Asiático e na Califórnia: uma perspectiva espacializada de Minsky. Economia e Sociedade 11: 73-136.

Eloy CM de M; Costa F de C and Rossetto R (2013) Subsídios na política habitacional brasileira: do BNH ao PMCMV. In: ANPUR (ed.) Encontros Nacionais da ANPUR. Recife: ANPUR, pp. 1-20.

Fernandes AC and Novy A (2010) Reflections on the unique response of Brazil to the financial crisis and its urban impact. International Journal of Urban and Regional Research 34: 952-966.

FGV Fundação Getúlio Vargas (2007) O Crédito Imobiliário no Brasil. São Paulo: FGV Projetos.

Fix M de AB (2011) Financeirizacão e transformações recentes no circuito imobiliário no Brasil. Campinas: Universidade de Campinas.

Fundação Perseu Abramo (2019) Os donos do dinheiro. O rentismo no Brasil. São Paulo: Fundação Perseu Abramo.

Furtado C (2005) A formação econômica do Brasil. São Paulo: Companhia Editora Nacional.

Granja PRS (2008) Modelo para avaliação do custo burocrático do FCVS: Um estudo de caso. Dissertação de mestrado. Escola brasileira de administração pública e de empresas, Fundação Getúlio Vargas, Rio de Janeiro.

Hilferding R (1910) Finance capital. London: Routledge \& Kegan Paul (1981 Edition).

Klink J (2013) Development regimes, scales and state spatial restructuring: Change and continuity in the production of urban space in metropolitan Rio de Janeiro, Brazil. International Journal of Urban and Regional Research 37: 1168-1187.

Klink J and Denaldi R (2014) On financialization and state spatial fixes in Brazil: A geographical and historical interpretation of the housing program My House My Life. Habitat International 44: 220-226. 
Klink J and Keivani R (2013) Development as we know it? Change and continuity in the production of urban and regional space in Brazil. International Journal of Urban Sustainable Development 5(1): 1-6.

Maricato E (2011) O impasse da Política Urbana. Rio de Janeiro: Editora Vozes.

Martins J de S (2010) O cativeiro da terra. São Paulo: Contexto.

Mello MABC (1988) Classe, burocracia e intermediação de interesses na formação da política de habitação. Revista Espaço e Debates 24: 75-85.

Ministry of finance/Secretaria do Tesouro Nacional (2015) Novação de dívidas do FCVS e Assunção de Dívidas pela União. Brasilia: Ministry of Finance.

Miranda JC and Tavares M de C (1999) Brasil: estratégias de conglomeração. In: Fior JL (ed.) Estados e Moedas no desenvolvimento das nações. Petrópolis, RJ: Vozes, pp. 327-350.

Myrdal G (1972) Teoria Econômica e regiões subdesenvolvidas. Rio de Janeiro: Saga.

Oliveira F de (1981) Elegia para uma re(li)gião: SUDENE, Nordeste, Planejamento e conflito de classes. 3rd Edition. Rio de Janeiro: Paz e Terra.

Oliveira F de (1988) O surgimento do Antivalor. Capital, força de trabalho e fundo público. Novos Estudos 22: 8-28.

Oliveira F de (1990) A metamorfose da arribaçã: fundo público e regulação autoritária na expansão econômica do Nordeste. Novos Estudos CEBRAP 27: 67-92.

Paulani LM (2008) A Crise do regime de acumulação com dominância da valorização financeira e a situação do Brasil. Estudos Avançados 23(66): 25-39.

Prado Jr C (1994) História Econômica do Brasil. São Paulo: Brasiliense.

Rangel I (1981) A história da dualidade brasileira. Revista da Economia Política 1(4): 5-34.

Royer L (2014) Financeirização da Política Habitacional: Limites e Perspectivas. São Paulo: FAU-USP.

Sanfelici D (2013) Financeirização e a produção do espaço urbano no Brasil: uma contribuição ao debate. Eure 39: 27-46.

Shimbo LZ (2012) Habitação social de Mercado. Belo Horizonte: Editora Arte.

Soja EW (1989) Postmodern geographies: The reassertion of space in critical social theory. London: Verso.

Tavares M de C (1999) Império, Território e dinheiro. In: Fior JL (ed.) Estados e Moedas no desenvolvimento das nações. Petrópolis, RJ: Vozes, pp. 449-489.

Topik S (1979) Capital estrangeiro e Estado no Sistema Bancário Brasileiro: 1889-1930. Revista Brasileira de Mercado de Capitais 5(15): 395-421.

Valença MM and Bonates MF (2010) The trajectory of social housing policy in Brazil: From the National Housing Bank to the Ministry of Cities. Habitat International 34(2): $165-173$.

Apparecido Jr JA (2017) Direito urbanístico aplicado: os caminhos da eficiência jurídica nos projetos urbanísticos. São Paulo: Juruá.

Blanco AGB; Cibils VF and Muñoz AFM (2016) Expandiendo el uso de la valorizacion del suelo. Washington: IADB.

Cardoso IC (2013) O papel da Operação Urbana Consorciada do Porto do Rio de Janeiro na estruturação do espaço urbano: uma "máquina de crescimento urbano"? O Social em Questão 16(29): 69-100.

Centro de Estudos da Metrópole (Cem). Lançamentos Imobiliários Comerciais e Residenciais da Base da Embraesp de 1985 a 2013. Available at: www.fflch.usp.br/centroda metropole/v3/bases.php?retorno=716\&language $=p t$ br (Accessed 20 December 2016).

Coma MC (2011) Del sueño olímpico al proyecto Porto Maravilha: el "eventismo" como catalizador de la regeneración a través de grandes proyectos urbanos. Revista Brasileira de Gestão Urbana 3(2): 211-227. 
D’Almeida CH (2019) Concessa Venia. Estado, empresa e a concessão da Produção do Espaço Urbano. Tese de Doutorado. Instituto de Arquitetura e Urbanismo, Universidade de São Paulo, São Carlos.

Da Silva M (2019) O fetiche dos instrumentos de solo criado: A experiência da aplicação da Cota de Potencial Construtivo em Curitiba. Dissertação de Mestrado. Faculdade de Arquitetura e Urbanismo, Universidade de São Paulo, São Paulo.

DiPasquale D and Wheaton W (1996) Urban economics and real estate markets. Upper Saddle River, NJ: Prentice Hall.

Fields D (2014) Contesting the financialization of urban space: Community organizations and the struggle to preserve affordable rental housing in New York City. Journal of Urban Affairs 37(2): 144-165.

Fix M (2009) Uma ponte para a especulação - ou a arte da renda na montagem de uma "cidade global". Caderno CRH 22(55): 41-64.

Halbert L and Attuyer K (2016) Introduction: The financialization of urban production: Conditions, mediations and transformations. Urban Studies 53(7): 1347-1361.

Klink J and Stroher LEM (2017) The making of urban financialization? An exploration of urban partnership operations with building certificates. Land Use Policy 69: 519-528.

Maleronka C (2010) Projeto e Gestão na Metrópole Contemporânea: um estudo sobre as potencialidades do instrumento operação urbana consorciada à luz da experiência paulistana. Tese de Doutorado. Faculdade de Arquitetura e Urbanismo, Universidade de São Paulo, São Paulo.

Maricato E (2001) Brasil, Cidades. Alternativas para a crise urbana. Petrópolis: Editora Vozes.

McAllister P (2017) The calculative turn in land value capture: Lessons from the English planning system. Land Use Policy 63: 122-129.

Odebrecht; OAS and URBEM (2016) I Pilares do projeto. II Empresa SA Complementacão à 20 fase do PMI do Arco Tiête. São Paulo: Prefeitura de São Paulo (Documento).

Ondetti G (2016) The social function of property, land rights and social welfare in Brazil. Land Use Policy 50: 29-37.

Pereira A (2016) Intervenções em centros urbanos e conflitos distributivos: modelos regulatórios, circuitos de valorização, e estratégias discursivas. São Paulo: Universidade de São Paulo.

PMC (Prefeitura Municipal de Curitiba) (2012) Prospecto da Operação Urbana Consorciada Linha Verde. Curitiba: PMC.

PMC (Prefeitura Municipal de Curitiba) (2015) OUC Linha Verde. Relatório Trimestral CVM. Curitiba: PMC.

PMRJ (Prefeitura Municipal do Rio de Janeiro) (2012) Prospecto da Operação Urbana Consorciada do Porto do Rio de Janeiro. Rio de Janeiro: PMRJ.

PMSBC (Prefeitura Municipal de São Bernardo do Campo) (2015) Estudo de Impacto de Vizinhança (EIV). Operação Urbana Consorciada São Bernardo do Campo. São Bernardo do Campo: PMSBC.

PMSP (Prefeitura Municipal de São Paulo) (2008) Prospecto da Operação Urbana Consorciada "Espraiada”. São Paulo: PMSP.

PMSP (Prefeitura Municipal de São Paulo) (2012) Prospecto da Operação Urbana Consorciada "Faria Lima". São Paulo: PMSP.

PMSP (Prefeitura Municipal de São Paulo) (2014a) Prospecto da Operação Urbana Consorciada "Branca". São Paulo: PMSP.

PMSP (Prefeitura Municipal de São Paulo) (2014b) Edital do Primeiro Leilão da Distribuição pública de CEPAC da Operação Urbana Consorciada "Branca". São Paulo: PMSP. 
PMSP/SP Urbanismo (2015a) Histórico de Leilões. OUC Espraiada. São Paulo: PMSP. PMSP/SP Urbanismo (2015b) Histórico de Leilões. OUC Faria Lima. São Paulo: PMSP.

Rezende F (2010) Em busca de um novo modelo de financiamento metropolitano. In: Magalhães F (ed.) Regiões Metropolitanas no Brasil. Um paradoxo de desafios e oportunidades. Washington: Banco Interamericano de Desenvolvimento, 264p.

Rolnik R (2018) Urban warfare: Housing under the empire of finance. London: Verso.

Royer L (2014) Financeirização da Política Habitacional: Limites e Perspectivas. Vol. 1. São Paulo: Annablume.

Salomão TMN (2016) Linguagem técnica e (im) possibilidade para a produção democrática do espaço urbano: uma análise a partir de duas experiências participativas em Belo Horizonte. Belo Horizonte: UFMG.

Sandroni P (2010) A new financial instrument of value capture in São Paulo: Certificates of additional construction potential. In: Ingram GK and Hong YH (eds.) Municipal revenues and land policy. Cambridge, MA: Lincoln Institute of Land Policy.

Savini F and Aalbers MB (2015) The de-contextualization of land use planning through financialization: Urban redevelopment in Milan. European Urban and Regional Development Studies: 1-17.

Siqueira MT (2014) Entre o fundamental e o contingente: dimensões da gentrificação contemporânea nas operações urbanas em São Paulo. Cadernos Metrópole, São Paulo 16(32): 391-415.

Smolka M (2013) Implementing value capture in Latin America: Policies and tools for urban development. Cambridge: Lincoln Institute of Land Policy.

Weber R (2010) Selling city futures: The financialization of urban redevelopment policy. Economic Geography 86(3): 251-274.

Aversa M (2016) História institucional do saneamento e da metropolização da grande São Paulo: trajetórias perdidas, conflitos inevitáveis. Dissertação de mestrado. UFABC, São Bernardo do Campo, SP.

Bahl RW and Linn JF (1992) Urban public finance in developing countries. Washington: Oxford University Press.

Barcellos de Souza M (2013) Variedades de capitalismo e reescalonamento espacial do Estado no Brasil. Tese de Doutoramento. Instituto de Economia, UNICAMP, Campinas.

Birch K (2017) Rethinking value in the bio-economy: Finance, assetization and the management of value. Science, Technology and Human Values 42(3): 460-490.

Britto AL and Rezende SC (2017) A política pública para os serviços urbanos de abastecimento de água e esgotamento sanitário no Brasil: financeirização, mercantilizacão e perspectivas de resistência. Cadernos Metrópole 19(39): 557-581.

CADE (Conselho administrative de defesa econômica) (2018) Pesquisa processual. Processo 08700.011091/2015-2018. Available at: https://sei.cade.gov.br/sei/modulos/pesquisa/ md_pesq_processo_exibir.php?0c62g277GvPsZDAxAO1tMiVcL9FcFMR5UuJ6rLq PEJuTUu08mg6wxLt0JzWxCor9mNcMYP8UAjTVP9dxRfPBcYwF7VPJpaiOt PaxB8YNJLtZLVCxY5rODYPctxCZ9E16 (Accessed 17 June 2017).

Callon M (1998) Introduction: The embeddedness of economic markets in economics: In: Callon M (ed.) The law of markets. Oxford: Blackwell, pp. 1-57.

Chiapello E (2015) Financialisation of valuation. Hum Studies 38: 13-35.

Christophers B (2014) From Marx to market and back again: Performing the economy. Antipode 57(1): 12-20.

Empinotti VL; Budds J and Aversa M (2018) Governance and water security: The role of the water institutional framework in the 2013-2015 water crisis in São Paulo. 
Geoforum. Online First. Available at: https://doi.org/10.1016/j.geoforum.2018.09.022 (Accessed 15 October 2018).

Ferreira LD (2019) Financiamento das políticas públicas de saneamento ambiental no Estado de São Paulo. In: XVIII Encontro da ANPUR, Natal, Brazil, May 27-31. Natal: ANPUR (Forthcoming).

GESP and PMSP (2010) State government and municipality of São Paulo. Contrato de prestação de serviços públicos de abastecimento de água e de esgotamento sanitário. Available at: www.saneamento.sp.gov.br/comitegestor/documentos/Contrato $\% 20 \mathrm{e} \% 20$ Convênio/Contrato_de\%20_Prestação.pdf (Accessed 1 September 2018).

Guironnet A and Halbert L (2015) Urban development projects, financial markets, and investors: A research note. Chairville: École des Ponts Paritech.

Hall S (2010) Geographies of money and finance I: Cultural economy, politics and place. Progress in Human Geography 35(2): 234-245.

Henrique SM (2017) A precificação dos serviços de saneamento de água e esgoto e o objetivo social. Masters Dissertation. UFABC, São Bernardo do Campo.

Hildyard N (2016) Licensed larceny. Manchester: Manchester University Press.

Kirkpatrick LO (2016) The new urban fiscal crisis: Finance, democracy, and municipal debt. Politics and Society 44(1): 45-80.

Lapavitsas C (2013) Profiting without producing: How finance exploits all of us. London and New York: Verso.

MacKenzie D (2006) An engine, not a camera: How financial models shape markets. Cambridge, MA: The MIT Press.

Ministério das Cidades (2018) SNIS (Sistema Nacional de informações sobre saneamento). Available at: http://app3.cidades.gov.br/serieHistorica/ (Accessed 2-4 September 2018).

Moody's Investors Service (2013) SABESP; Perspectiva estável. Available at: www. sabesp.com.br/sabesp/filesmng.nsf/15652B2BF431F72083257BAA00719176/\$File/ PR_Sabesp_Port.pdf (Accessed 5 May 2018).

Peck J and Whiteside H (2016) Financializing Detroit. Economic Geography 92(3): 235-268.

Pryke M and Allen J (2019) Financialising urban water infrastructure: Extracting local value, distributing value globally. Urban Studies 56(7): 1326-1346.

Rezende F (2010) Em busca de um novo modelo de financiamento metropolitan. In: Magalhães F (ed.) Regiões Metropolitanas no Brasil. Washington: BID, pp. 45-98.

SABESP (2017) Relatório Annual. São Paulo: SABESP.

SEMASA (2018) Avaliação econômico-financeira (Valuation). Relatório apresentado à superintendência pela FGV. Santo André: SEMASA.

Swyngedouw E (2013) Águas revoltas. A economia política dos serviços públicos essenciais. In: Heller E and Esteban Castro JE (eds.) Política pública e gestão de serviços de saneamento. Belo Horizonte and Rio de Janeiro: Editora UFMG \& Editora Fio Cruz, pp. 76-97.

Van Loon J; Oosterlynck S and Aalbers MB (2018) Governing urban development in the low countries: From managerialism to entrepreneurialism and financialization. European Urban and Regional Studies: 1-19. Available at: https://doi.org/10.1177/0969776418 798673

Weber R (2010) Selling city futures: The financialization of urban redevelopment policy. Economic Geography 86(3): 251-274.

Zwan vd N (2014) Making sense of financialization. Socio-Economic Review 12: 99-129. Acolin A; Hoek-Smit MC and Eloy CM (2019) High delinquency rates in Brazil's Minha Casa Minha Vida housing program: Possible causes and necessary reforms. Habitat International 83: 99-110. 
Amore CS; Shimbo LZ and Rufino MBC (eds.) (2015) Minha Casa . . . E A Cidade? Avaliação do Programa Minha Casa Minha Vida em seis estados Brasileiros. Rio de Janeiro: Letra Capital.

Arcanjo RT (2016) O Programa Minha Casa Minha Vida e o desenquadramento nas Faixas II e III: estudo de caso da região do ABC Paulista. Dissertação de Mestrado. Programa em Planejamento e Gestão do Território, UFABC, Santo André.

Brasil (2013) Programa Minha Casa Minha Vida. Brasília: Ministério das Cidades.

Cardoso AL (ed.) (2013) O Programa Minha Casa Minha Vida e seus Efeitos Territoriais. Rio de Janeiro: Letra Capital.

CEF (Caixa Econômica Federal) (2015) Balanço Físico-financeiro dos empreendimentos $P M C M V$ na região do Grande ABC. Santo André: CEF.

DiPasquale D and Wheaton W (1996) Urban economics and real estate markets. Upper Saddle River, NJ: Prentice Hall.

Denaldi R (2013) Trapped by the land? Change and continuity in the provision of social housing in Brazil. International Journal of Urban Sustainable Development 5(1): 40-53.

Eloy CM de M; Costa F de C and Rossetto R (2013) Subsídios na política habitacional brasileira: do BNH ao PMCMV. In: ANPUR (ed.) Encontros Nacionais da ANPUR. Recife: ANPUR, pp. 1-20.

Ferreira JSW (ed.) (2012) Produzir casas ou construir cidades? Desafios para um Brasil urbano. Parâmetros de qualidade para a implementação de projetos habitacionais urbanos. São Paulo: LABHAB and FUPAM.

Freitas FG; Whitehead C and Rosa JS (2015) Finance and subsidy policies in Brazil and European union: A comparative analysis. Brasilia, DF: MCidades; SNH; MPOG and Cities Alliance.

Hoek-Smit MC and Diamond DB (2003) Subsidizing housing finance. Housing Finance International 18(2): 3-13.

Hoyler TA (2014) Produção habitacional via mercado: quem produz, como e onde? In: Marques E (ed.) São Paulo nos anos 2010. As transformações da metrópole. São Paulo: Unesp.

Klink J and Denaldi R (2014) On financialization and state spatial fixes in Brazil: A geographical and historical interpretation of the housing program My House My Life. Habitat International 44: 220-226.

Klink J and Denaldi R (2015) On urban reform, rights and planning challenges in the Brazilian metropolis. Planning Theory: 1-16.

Klink J; Fonseca MLP de; Royer L; Feitosa F; Mello LF de; Sampaio L; Diniz J; Arcanjo RT; Alvarez G; Nogueira K; Sorrenti L and Peixoto T (2016) Avaliação do Programa "Minha Casa Minha Vida" em São Paulo-SP e da Região do Grande ABC-SP. Santo André: UFABC Relatório de Pesquisa. Chamada MCTI/CNPQ No 14/2013.

Krause C; Balbim R and Neto VCL (2013) Minha Casa Minha Vida, Nosso Crescimento: Onde Fica a Política Habitacional? Brasília: IPEA.

Magalhães I (2013) Planos Locais de Habitação na estratégia da Política Nacional de Habitação. In: Denaldi R (ed.) Planejamento Habitacional: notas sobre precariedade e terra nos Planos Locais de Habitação. São Paulo: Annablume, pp. 13-27.

Marques E and Rodrigues L (2013) O Programa Minha Casa Minha Vida na Metrópole Paulistana: Atendimento Habitacional e Padrões de Segregação. Revista Brasileira de Estudos Urbanos e Regionais 15(2): 159-177.

Mendonça MJ and Sachsida A (2012) Existe Bolha no Mercado Imobiliário Brasileiro? Rio de Janeiro: IPEA. 
Pereira EC da (2019) Preços Imobiliários e Ciclos Econômicos nos anos 2000: Uma Abordagem Heterodoxa. Campinas: Universidade Estadual de Campinas, Dissertação de Mestrado em Desenvolvimento Econômico, Instituto de Economia.

Rodríguez-Pose A; Tomaney J and Klink J (2001) Local empowerment through economic restructuring in Brazil: The case of the Greater ABC region. Geoforum 32: 459-469.

Rolnik R et al. (2015) O programa Minha Casa Minha Vida nas regiões metropolitanas de São Paulo e Campinas: aspectos socioespaciais e segregação. Cadernos Metrópole 33: $127-154$.

Royer L (2014) Financeirização da Política Habitacional: Limites e Perspectivas. São Paulo: Annablume.

Souza CVS de (2018) Problematizando a reforma urbana no Brasil: Uma Abordagem de Escalas e Regimes de Organização e Intervenção Territorial do Estado. Tese de Doutorado, Programa de Planejamento e Gestão do Território, Universidade Federal do ABC, São Bernardo do Campo.

Shimbo LZ (2012) Habitação social de Mercado. Belo Horizonte: Editora Arte.

UFABC (Universidade Federal do ABC) (2016) Plano diretor regional. Relatório final entregue ao Consórcio Intermunicipal Grande ABC, UFABC, Santo André.

World Bank (1993) Housing: Enabling markets to work. Washington: International Bank for Reconstruction and Development.

Addison F and Artioli F (2019) Four type of urban austerity: Public land privatisations in French and Italian cities. Urban Studies. Online First. Available at: https://doi.org/ 10.1177/0042098019827517 (Accessed June 17, 2019).

Affonso BA de and Silva PLB (eds.) (1995) A Federação em perspectiva: Ensaios selecionados. São Paulo: FUNDAP.

Alke J (2018) Authoritarian neoliberal rescaling in Latin America: Urban in/security and austerity in Oaxaca. Globalizations: 1-16.

Arampatzi A (2017) The spatiality of counter-austerity politics in Athens, Greece: Emergent "urban solidarity spaces". Urban Studies 54(9): 2155-2171.

Armondi S (2017) State rescaling and new metropolitan space in the age of austerity: Evidence from Italy. Geoforum 81: 174-179.

Baker T and Temenos C (2015) Urban policy mobilities research: Introduction to a debate. International Journal of Urban and Regional Research 39(4): 824-827.

Bayırbağ MK; Davies JS and Münch S (2017) Interrogating urban crisis: Cities in the governance and contestation of austerity. Urban Studies 54(9): 2023-2038.

Brenner N (2004) New state spaces: Urban governance and the rescaling of statehood. Oxford: Oxford University Press.

Brenner N; Peck J and Theodore N (2010) Variegated neoliberalization: Geographies, modalities, pathways. Global Networks 10(2): 182-222.

Canettieri T (2017) A produção capitalista do espaço e a gestão empresarial da política urbana: o caso da PBH Ativos S/A. Revista brasileira de estudos urbanos e regionais 19(3): 513-529.

CNACD (Coordenação Nacional da Auditoria Cidadã da Dívida) (n.d) Projetos cifrados. PLS 204/2016, PLP 181/2015 e PL 3337/2015 visam “legalizar" esquema fraudulento. Brasília: CNACD.

Costa FN da (2012) Brasil dos bancos. São Paulo: EDUSP.

Engelen E and Glasmacher A (2018) The waiting game: How securitization became the solution for the growth problem of the Eurozone. Competition \& Change 22(2): 165-183.

Fattorelli ML and Gomes JM (2018) Securitização de créditos: Desvio de arrecadação e geração de dívida pública illegal. Revista Direitos, Trabalho e Política Social 4(7): 165-199. 
Fiori JL (1999) Estados e Moedas no Desenvolvimento das nações. Petrópolis: Vozes.

Fuller C and West K (2017) The possibilities and limits of political contestation in times of "urban austerity". Urban Studies 54(9): 2087-2106.

Hall S and Jonas AEG (2014) Urban fiscal austerity, infrastructure provision and the struggle for regional transit in "Motor City". Cambridge Journal of Regions, Economy and Society 7: 189-206.

Hinkley S (2017) Structurally adjusting: Narratives of fiscal crisis in four US cities. Urban Studies 54(9): 2123-2138.

Keating M (2013) Rescaling the European state: The making of territory and the rise of the meso. Oxford: Oxford University Press.

Kirkpatrick LO (2016) The new urban fiscal crisis: Finance, democracy, and municipal debt. Politics \& Society 44(1): 45-80.

Klink J (2001) A Cidade-região. Regionalismo e reestruturação no Grande ABC Paulista. Rio de Janeiro: Editora DPA.

Klink J (2018) Metrópole, moeda e mercados. A agenda urbana em tempos de reemergência das finanças globais. Cadernos Metrópole 20(43): 717-742.

Marcuse P (1981) The targeted crisis: On the ideology of the urban fiscal crisis and its uses. International Journal of Urban and Regional Research 5(3): 330-354.

Martí-Costa M and Tomàs M (2017) Urban governance in Spain: From democratic transition to austerity policies. Urban Studies 54(9): 2107-2122.

McCann E (2011) Urban policy mobilities and global circuits of knowledge: Toward a research agenda. Annals of the Association of American Geographers 101(1): 107-130.

McCann E and Ward K (2013) A multi-disciplinary approach to policy transfer research: Geographies, assemblages, mobilities and mutations. Policy Studies 34(1): 2-18.

Nascimento ER and Debus I (2001) Lei Complementar No 101/2000. Entendendo A Lei de Responsabilidade Fiscal. Brasilia: Secretaria do Tesouro Nacional, Ministério da Fazenda.

O'Connor J (1973) The fiscal crisis of the state. New York: St Martin's Press.

Oliveira F de (1998) Os Direitos do antivalor. Petrópolis: Vozes.

Oosterlynck S and Gonzales S (2013) "Don't waste a crisis": Opening up the city yet again for neoliberal experimentation. International Journal for Urban and Regional Research 37(3): 1075-1082.

Peck J (2017a) Transatlantic city, part 1: Conjunctural urbanism. Urban Studies 54(1): 4-30.

Peck J (2017b) Transatlantic city, part 2: Late entrepreneurialism. Urban Studies 54(2): 327-363.

Peck J and Whiteside H (2016) Financializing Detroit. Economic Geography 92(3): 235-268.

Tavares MdC and Fiori JL (eds.) (1997) Poder e Dinheiro. Uma Economia política da globalização. Petrópolis: Vozes.

Baker T and Temenos C (2015) Urban policy mobilities research: Introduction to a debate. International Journal of Urban and Regional Research 39(4): 824-827.

Brenner N (2000) The urban question as a scale question: Reflections on Henri Lefebvre, urban theory and the politics of scale. International Journal of Urban and Regional Research 24(2): 361-378.

Brenner N (2004) New state spaces: Urban governance and the rescaling of statehood. Oxford: Oxford University Press.

Christophers B (2014) From Marx to market and back again: Performing the economy. Antipode 57(1): 12-20.

Fainstein SS (2000) New directions in planning theory. Urban Affairs Review 35(4): 451-478. 
Fainstein SS and Campbell S (eds.) (2012) Readings in planning theory. West Sussex: Blackwell Publishers.

Healey P (2003) Collaborative planning in perspective. Planning Theory 2(2): 101-123.

Healey P (2011) The universal and the contingent: Some reflections on the transnational flow of planning ideas and practices. Planning Theory 11(2): 188-207.

Healey P (2013) Circuits of knowledge and techniques: The transnational flow of planning ideas and practices. International Journal of Urban and Regional Research 37(5): $1510-1526$.

Holston J (2009) Insurgent citizenship in an era of global urban peripheries. City \& Society 21(2): 245-267.

Klink J and Denaldi R (2015) On urban reform, rights and planning challenges in the Brazilian metropolis. Planning Theory 15(4): 402-417.

Maricato E (2011) O impasse da política urbana. Petrópolis: Vozes.

McCann E (2011) Urban policy mobilities and global circuits of knowledge: Toward a research agenda. Annals of the Association of American Geographers 101(1): 107-130.

Miraftab F (2009) Insurgent planning: Situating radical planning in the Global South. Planning Theory 8(1): 32-50.

Peck J and Theodore M (2015) Fast policy: Experimental statecraft at the thresholds of neoliberalization. Minneapolis: University of Minnesota Press.

Purcell M (2009) Resisting neoliberalization: Communicative planning or counter-hegemonic movements? Planning Theory 8(2): 140-165.

Randolph R (2008) A nova perspectiva do planejamento subversivo e suas (possíveis) implicações para a formação do planejador urbano e regional - o caso brasileiro. Scripta Nova 12(270): 98. Available at: www.ub.edu/geocrit/sn/sn-270/sn-270-98.htm

Robinson J (2015) “Arriving at" urban policies: The topological spaces of urban policy mobility. International Journal of Urban and Regional Research 39(4): 831-834.

Savini F and Aalbers M (2016) The de-contextualisation of land use planning through financialisation: Urban redevelopment in Milan. European Urban and Regional Studies 23(4): 878-894. 